\title{
Government Shareholding and the Value of China's Modern Firms
}

\author{
By: Lihui Tian
}

William Davidson Working Paper Number 395

April 2001 


\title{
G overnment Shareholding and the $V$ alue of China's M odern Firms
}

First Draft: May 01, 1999

This Draft: April 28, 2001

\section{Lihui Tian}

\begin{abstract}
This paper documents the ultimate shareholding structures of 826 corporations listed on China's stock market and finds large equity holdings of the government. Using a panel data set, this paper further finds that corporate value decreases with an increased size of government shareholding when the government is a small shareholder. When the government equity holding is sufficiently large, corporate value increases with increased government shareholding. This Ushaped relationship between government shareholding and corporate value is interpreted by the aggregated impacts of the grabbing and helping hands of the government shareholder.
\end{abstract}

JEL classification: G32, G34, G 15, L 33

Key words: ownership structure, government shareholding, corporate governance.

\footnotetext{
* "George" Lihui Tian, London Business School, Regent's Park, London NW1 4SA, UK; Email: $\underline{\text { LTian@london.edu }}$

I am grateful to Saul Estrin and Julian Franks. My research has also benefited from the comments of James Ang, William Megginson, Larry Lang, Mario Nuti, Enrico Perotti, Lawrence Rose, Henri Servaes, Oren Sussman, Eli Talmor, Paolo Volpin and participants of the seminar at the London Business School, the Lancaster University Management School, the Cardiff Business School, the Brunel University, the Fortis International Finance Conference, the European Finance Association Conference and the CEPR/WDI International Conference on Transition Economics. Data collection for this paper would not have been possible without the help of Dr. Yaping Xu from the China Securities Regulatory Commission, Hui Gong from the Genius Co. and Yun Xia from the Hairong Co.. This paper has also benefited from the interviews with investment professionals or general managers. Particularly, I am grateful to Dazhang Zhao, Dr Zhaoyang Chen, Dr Houqi Zhang from the Hua Xia Securities Co., Dr Xuedong Fu from the Guotai Junan Securities Co., Marcel Zu and Xiaoming Lu from the GF Securities Co., Dr Victor Xu from the China Eagle Securities Co., Dr Hua Yu from the Shenzhen Stock Exchange, Song Fan from Shenzhen Lionda Holding Co. Ltd., Guangsheng Zheng from Millennium Investing (Shanghai) Co.. The financial support of the London Business School is acknowledged. Any remaining errors are my own.
} 
William Davidson Institute Working Paper 395

CHINA'S STOCK MARKET has developed rapidly since it was founded ten years ago. The companies listed on this stock market are the modern Chinese firms, representing a new enterprise system in China. However, the features of the these Chinese public listed companies (PLCs) largely remain unknown. This paper examines the shareholding structures of these Chinese modern firms and finds a nonmonotonic impact of government shareholding on corporate value.

Using the method of La Porta, Lopez-de-Silanes and Shleifer (LLS, 1999), this paper documents the ultimate shareholding structures of firms listed on the Chinese stock market. The separation of cash flow rights and voting rights through pyramids and cross-shareholding is found to be marginal, but the control is highly concentrated in China. Furthermore, it is found that the government is the majority shareholder of $31.4 \%$ of the PLCs. This paper therefore suggests that, compared with western firms, the key to understanding these Chinese modern firms is the role of the government shareholder. This paper is devoted to studying the impact of state shareholding on corporate value.

The data used in this paper is the ownership, accountancy and share price data of all the firms listed on the Shanghai Securities Exchange and the Shenzhen Stock Exchange. With this panel dataset of 2660 firm-year observations, this paper finds that mixed enterprises 1 are valued lower than the enterprises without any government shareholding stakes and the firms under the control of the government shareholder are valued lower than those firms under the control of the a non-government shareholder. The overall impact of state shareholding is negative on corporate value in China's PLCs. It is consistent with the literature of inefficiency of state ownership ${ }^{2}$. Following the research approach of Morck, Shleifer and Vishny (1988) and McConnell and Servaes $(1990)^{3}$, this paper, however, does not find a monotonic 
William Davidson Institute Working Paper 395

negative relationship between the sizes of government shareholding stakes and corporate value. It is found a U-shaped relationship with a higher left end than the right end between state shareholding and the value of firms. In other words, when the government is a small shareholder, corporate value decreases with increased sizes of the government shareholding stakes. This is consistent with the grabbing hand hypothesis of the government shareholder. When the shareholding stake of the government is sufficiently large, corporate value is higher in the firms with a larger stake of government shareholding. It suggests that the government shareholder has a helping hand as well.

This paper interprets this U-shape with the organizational view of the government. That is, the government shareholder acts on maximizing its utility functions. To maximize both its political interests and financial interests, the government shareholder provides both the grabbing and helping hands to the firms. With increased control rights of the government shareholder, the probability and the extent of the expropriation of the government shareholder increases and corporate value decreases until a certain threshold. When the cash flow rights of the government shareholder are sufficiently large, the government, however, has no incentives to continue to increase the magnitude of its predation in this firm. In contrast, with a large shareholding stake, the government shareholder offers a helping hand to these firms. Because of its financial interest based on corporate profits, the large government shareholder has incentives to improve corporate value for the residual cash flows by monitoring the managers and providing preferential treatments. This paper makes an attempt to provide support to this interpretation, with studying employee-welfare expense, board-member turnovers and explicit government subsidies. 
William Davidson Institute Working Paper 395

By documenting the shareholding structure of Chinese firms, this paper contributes to the map of ownership structures around the world (LLS 1999, Claessens et al. 2000 and Faccio and Lang 2000). Furthermore, with the initiative on studying a particular shareholder - the government, this study contributes to the knowledge of the impacts of shareholding structures on firm value (Shleifer and Vishny 1997). With the evidence from China, this paper consolidates the static mixenterprises literature (e.g. Boardman and Vining 1989) and the dynamic privatization literature (e.g. Megginson et al. 1994). More importantly, examining the influence of state shareholding as well as some other corporate finance factors, this paper helps to understand the firms on the Chinese stock market.

This paper proceeds as follows. Section I describes the dataset and documents the shareholding structures of the firms on China's stock market. Section II reviews the state ownership literature and describes testable hypotheses. The econometric methods are presented in Section III. Section IV presents the empirical findings of the impact of government shareholding. Section V interprets the U-shape finding and provides further evidences. Section VI concludes this paper.

\section{Shareholding Structures and Corporate Features}

This section introduces the data sample from the Chinese stock market, documents the shareholding structures of these PLCs and discusses some other characteristics of these firms. It is found that the government shareholder in control is a main characteristic of the Chinese PLCs. 
William Davidson Institute Working Paper 395

A. China's stock market and data sample

The Chinese stock market is composed of the Shanghai Securities Exchange (SHSE) and the Shenzhen Stock Exchange (SZSE), which started operation in December 1990 and July 1991, respectivelys. The regulatory authority is the China Securities Regulation Commission (CSRC), founded in October 1992. It stipulates disclosure rules and governance regulations.

The Chinese stock market has grown rapidly. Between 1992 and 1998, the market capitalization increased at the average rate of $84.7 \%$ per year. At the end of 1998, the total market capitalization was about a quarter of China's GDP. The number of listed companies grew 62.0\% annually, from 53 PLCs in 1992 to 851 PLCs in 1998.

The data used in this paper is based on the audited annual reports from the PLCs and share price data from the stock exchanges. Internationally, the leading data vender is the Taiwan Economic Journal (TEJ), but the TEJ database has a large number of missing values. The domestic investment bankers and security analysts tend to use the Genius database. A new dataset was therefore been assembled based on these two databases and several other complementary sources (see appendix 1). This newly assembled dataset covers the accounting information, the holding stakes of large shareholders and daily share prices from 1994 to 1998 . The regulatory framework is relatively consistent during this period 5 . The description of corporate features and mapping of the ownership structures are based on the most recent data of 1998.

My data sample excluded fund management companies, as their operations are distinctly different from industrial firms ${ }^{6}$. It also excluded the firms that do not issue shares for domestic investors ${ }^{7}$. The sample used to examine the relationship between 
William Davidson Institute Working Paper 395

state shareholding and corporate value includes 287 companies in 1994, 311 in 1995, 517 in 1996, 719 in 1997 and 826 in 1998. Altogether, the main dataset used in this paper have 2660 firm-year observations.

\section{B. Corporate characteristics of Chinese PLCs}

A simplified aggregate balance sheet of my data sample is presented in Table II and the following briefly describes the features of these modern Chinese firms.

\section{B.1 Leverage}

Table II shows that the ratio of total liability to total asset, is $49 \%$. The debt to total asset ratio is $21 \%$. Debt finance in PLCs is mainly in the form of loans, as the market of corporate bonds does not exist. Overall, China's PLCs are not heavily indebted. The average current ratio of quoted companies is 2.0 and quick ratio 1.5, indicating that their liquidity is generally adequate. This is different from these government-solely-owned enterprises (SOEs) in China.

\section{B.2 Size}

The average total asset of China's PLCs was US\$ 180 million and the average fixed asset was $\$ 50$ million, $53 \%$ of total assets was current assets and $36 \%$ was fixed assets. The average net asset per share was 0.31 US dollar and the average earning per share was 0.025 US dollar in 1998.

\section{B.3 Age}

The listed companies have an average age of 14 years and the median is 7 years. Most of the listed companies are newly formed or restructured during the reform period of China. They are different from the SOEs, most of which were founded under the former central planning system.

\section{B.4 Governance}




\section{William Davidson Institute Working Paper 395}

The corporate governance structure of these Chinese companies is, in essence,

the one-tier board structure..$^{0}$ At the shareholders' annual general meeting, the Board of Directors is elected. The board of directors appoints the general manager, approves the annual accounts and corporate strategy. They monitor corporate management and have the power to intervene if necessary. Like the CEO in the United States, the general manager is in charge of the daily operation.

\section{B.5 Managerial shareholding}

The top management team can also be the shareholders of the company, but the shares held by the managers and directors are not allowed to be transferred during their tenure. The managerial shareholdings are required to be disclosed to the public. Under the constraints of personal wealth in China, the average managerial ownership was as small as $0.005 \%$ of the total shares.

\section{Shareholding structures of Chinese quoted firms}

The above section shows that the Chinese PLCs are organized and operated under the model of the modern western firms. However, the shareholding strucutres of the Chinese PLCs are somewhat particular. This section first describes the official classification of shares and argues that it is confused with tradability and ownership. Then presented is the ultimate ownership structure of China's PLCs under the methodology of LLS (1999) is presented

In the Chinese stock market, share ownership is officially classified by and reported as state, legal-person, employee, and tradable-A shares, and shares denominated in a foreign currency. Although there are multiple classes of stocks in these Chinese PLCs, all the common shares bear the same rights for voting and cash flow. The one-share-one-vote rule is followed in all the PLCs with all the shares. 


\section{William Davidson Institute Working Paper 395}

The above classification was to facilitate the regulation of the trading activities rather than classifying the investors. It is confused institutional shareholders with legal-person shares, and confuses foreign shareholders with the shares denominated in foreign currency. However, most of the existing research on the impact of shareholding structures on corporate value in China's quoted companies (Xu and Wang 1999, Qi et al. 2000) use this classification.

This paper follows the cutting-off methods of LLS (1999) and Franks and Meyer (2000) to document the ultimate shareholding structures of these Chinese firms. This method traces down the ultimate shareholder with a holding larger than a certain threshold 11 by examining pyramids, cross-shareholdings and reciprocal shareholdings. For example, the $10 \%$ threshold traces only the ultimate shareholders

that hold more than $10 \%$ of the company. A pyramid is defined as an entity that owns one public listed company, which in turn owns another corporation, as so on. Cross-shareholdings are defined as a condition that exists when a company has a controlling shareholder and owns shares in a firm that belongs to its chain of control. Reciprocal shareholding is the case that a company owns part of itself. The calculations of ultimate shareholding rights is based on the lowest holding rights in the chain to trace the ultimate shareholders.

In China, the sizes of the shareholding stakes of the largest ten shareholders are requested to be released to the public. Based on the names of 846 PLCs and the ten largest shareholders in 1998, it was found that there is another quoted company among the ten largest shareholders of 167 companies. However, even by the minimal threshold of $10 \%$, only 19 firms are pyramids or cross-shareholdings. That is, there were only 19 cases where an ultimate shareholder holds this company more than $10 \%$ through another quoted company. Meanwhile, this paper found that, by the $10 \%$ 
William Davidson Institute Working Paper 395

cutting-off level, the ratio of cash flow rights to voting rights was $99 \%$ and thus the separation of ownership and control is marginal ${ }^{13}$.

Panel A in Table IV summarizes the shareholding fractions of the ultimate owners who is the largest shareholder, or owns larger than $50 \%, 30 \%$ or $10 \%$ of voting equity in my data sample of 846 quoted companies in 1998. The government shareholder is the largest shareholder of $44 \%$ of the sampled PLCs and the majority shareholder of $31 \%$ of the sampled PLCs. If $30 \%$ of voting shares is taken as the threshold for control, the government controls $38 \%$ of the sampled PLCs. If $10 \%$ of voting shares is taken as the threshold for control, the government controls $44 \%$ of the sampled PLCs. Comparing with the findings in developed economies $\frac{14}{14}$ the government shareholder in control is a salient feature of these Chinese firms. It is mandatory to understand the impact of government shareholding in order to understand these modern Chinese firms.

There is no individual or household family owning more than $10 \%$ of the shares in a Chinese PLC. It is actually stipulated by the government that no single individual investment account is allowed to hold more than $0.5 \%$ of one PLC. Thus a rich family has to disguise itself as a private joint-stock company and then this company may hold a large block of shares in a PLC, for example, Xinfu Shiye. The cases of disguised large family shareholders are, however, very few. 15

The Chinese government holds the majority stakes of more than $30 \%$ of companies. If we assume that the largest shareholder is in control of a company, then the government controls $44 \%$ of quoted firms through its shareholdings. State shareholding is a salient feature of these Chinese firms $\frac{16}{16}$.

Panel B in Table IV shows a highly concentrated ownership structure. On average, the five largest shareholders account for $60.6 \%$ of the total outstanding 


\section{William Davidson Institute Working Paper 395}

shares, compared with $25.4 \%$ in United States and 33.1\% in Japan (Prowse 1998). More strikingly, the largest shareholder holds more than $40 \%$ of the equity in these Chinese PLCs. It is consistent with the institutional underpinning, as the weak legal protection of investors demand a concentrated shareholding structure (LLSV 1998).

The above analysis shows that the control of the government shareholder is substantial in the PLCs, which features the Chinese socialist characteristics. Therefore, a main difference of these Chinese modern firms from western modern firms is the significant large shareholding rights of the government. Understanding the impacts of the government shareholder is imperative to understand China's PLCs.

\section{State sharehol ding in Chinese firms}

State shareholding is calculated as the proportion of state-owned shares to total shares. State-owned shares are the shares directly owned by the government or its wholly-owned economic institutions. The government is composed of the central government and local governments, but the heads of the local governments are normally assigned by the central government in China. The central government is essentially the owner of state-owned shares. The senior staff of the holding institutions of state-shares are government functionaries. The bureaucrats managing state shares differentiate the government shareholder from other shareholders. Government functionaries serve the governmental interests to collect revenues from corporate operation and reallocate resources for political purpose.

OECD (2000) concludes that even the Chinese government's newly established holding companies continue to be more bureaucratically, rather than commercially, oriented. In case branches of the central government or local governments directly hold the state shares, the influences of bureaucrats are more 
William Davidson Institute Working Paper 395

obvious. Given that the state-shares are managed and controlled under the government bureaucratic hierarchy, this paper actually studies the impact of bureaucracy shareholding 17 .

For example, the government holds $88.6 \%$ in the firm Qinggong Machinery 18 . The other shareholders in Qinggong Machinery are family investors and some township-village enterprises. The government's agent that controls this shareholding is the Shanghai Electronics Group which is fully owned by the state and operated like a department of the Shanghai Municipal Government. The mayor of Shanghai government and his management committee, who is assigned by the central government in Beijing, decides the appointment of the general managers in both the Shanghai Electronics Group and the Qinggong Machinery. Appendix 2 shows the organizational structure of the regional state-shareholding management system in Shanghai City. It suggests that state shares have one ultimate owner.

\section{E. Corporate value and profitability}

This section introduces the proxies of corporate value and presents the descriptive statistics pertaining to the relationship between state shareholding and corporate value.

Tobin's Q (Lindenberg and Ross 1981) is an adjusted measure of the market value of the firm. This paper uses the simplified version of Tobin's Q (Perfect and Wiles 1994; Chung and Pruitt 1994) as the substitute for the actual Tobin's $\mathrm{Q}^{19}$. This simplified Tobin's Q, heneforth known as Q, is the sum of market value of equity and book value of debt over book value of total assets. It has been widely adopted in corporate finance literature to avoid the arbitrary assumptions about depreciation and inflation rates (e.g. Shin and Stulz, 1998). 


\section{William Davidson Institute Working Paper 395}

To be cautious with the market efficiency issue in China, another measure of corporate performance is needed. The value of a firm is decided by its profitability. Following conventions of corporate finance literature, return on assets (ROA) is used as the proxy for profitability; ROA equals the net earnings divided by the total assets.

To understand the relationship between state shareholding and corporate value, Table V presents Q and ROA in the firms under the 10\% percentile distribution of the size of state shareholding stakes. About one third of companies have no state shareholding and their profitability seems to be selective to that of other companies high. Then, as the stake of state shareholding increases, corporate value seems to decrease. This trend reverses once state shareholding reaches about $40 \%$. Finally, when state shareholding is in the $80 \%$ to $90 \%$ range, corporate value again seems to decrease. However, there are few firms in this range and this simple statistics can be highly influenced by outliers. It needs rigorous econometric investigations.

\section{Literature of State $\mathbf{O}$ wnership and Hypotheses}

The government is the largest shareholder of these Chinese companies. This section briefly reviews the literature of government ownership and proposes testable propositions about state shareholding.

\section{A. Detrimental government ownership}

The property rights theory argues that the fatal flaw of SOEs - the state fully owned enterprises-is the principal-agent problem. Because of information asymmetry and incentive incompatibility, agency problems surface when the owner cannot operate the firm itself and has to delegate the control to the managers. The managers in SOEs, therefore, have no incentive to maximize corporate profitability. 
William Davidson Institute Working Paper 395

However, among the public listed firms that are large and publicly financed, the separation of ownership and control is a common feature ${ }^{20}$, regardless of whether or not the government is a shareholder. Stiglitz (1994) argues that "... the nature of those principal-agent problems may differ little depending on whether ownership is public [state] or private." This principal-agent problem does not necessarily suggest the inefficiency of government shareholding in the PLCs.

Another flaw of state ownership is political interference (Kornai 1980, 1992). This applies to the partial state ownership in the large modern firms. Based on the voting rights from holding shares, the government can interfere with corporate management. Ideally, a government tries to improve total social welfare rather than corporate profitability. In reality, the government pursues its political interests (Shleifer and Vishny 1994). The politicians through the control rights of state shareholding may deliberately transfer resources of firms to their political supporters (Shleifer and Vishny 1998). These would normally be at the expense of corporate profitability (Shapiro and Willig 1992, Boycko et al. 1996).

The empirical literature of state ownership can be classified into the dynamic and static approach. Much of this literature supports the theoretical view that state ownership is detrimental to corporate value. Comparing corporate performance before and after privatization, the dynamic approach finds that reducing or eliminating state ownership improves corporate performance and concludes that therefore the government ownership is generally detrimental (e.g. Megginson et al 1994). The studies that have compared state-fully-owned enterprises, mixed enterprises and private enterprises over the same period are static. Although their samples of mixed enterprises are small, most of these studies find that private enterprises outperform mixed enterprises and state-fully-owned enterprises (eg. Boardman and Vining 1989), 
William Davidson Institute Working Paper 395

and thus the static research also suggests that government shareholding is detrimental to corporate profitability.

\section{B. Testable hypotheses}

Based on the grabbing hand view of government ownership (Shleifer and Vishny 1998), the following hypotheses are developed.

Hypothesis 1: The companies with partial state ownership are valued lower than those without any state ownership.

State shareholding provides the channel for the government to intervene

corporate management ${ }^{2-1}$ for its political purpose. The firms without partial state ownership should have less political interference and therefore higher value.

Hypothesis 2: The companies in which a government is the controlling shareholder are valued lower than those with a non-government controlling shareholder.

Corporate value possibly depends on whether the government shareholder is able to stay in control of the management team. This hypothesis develops the first hypothesis within the context of joint-stock companies.

Hypothesis 3: Corporate value is a negative function of the voting rights of the government shareholder.

This hypothesis further develops the detrimental view of the government that is a shareholder. The power and influence of a shareholder is based on its voting rights. With increasing influence of the government shareholder, and therefore the probability and magnitude of political interference, corporate value should decrease. 
William Davidson Institute Working Paper 395

\section{Econometric Models and Predications}

To test the above hypotheses, this section first describes the investigation procedures and the related econometric models. The choice of control variables are also discussed here. In addition, it briefly describes the robustness tests performed.

\section{A. Econometric methods}

The econometric investigations begin with comparison analyses and then focus on regression analyses. Student-t statistics were used to examine the differences between means. In order to control for the outliers effect, the non-parametric MannWhitney $U$ tests to investigate the significance of median difference were also performed. As for the regression analyses, the tables report the results of the pooled ordinary linear regressions adjusted by White robust estimators (OLS) and the maximum log likelihood panel data estimation (MLP).

OLS estimation with the robust standard errors produces consistent standard errors even if the data is weighted or the residuals are not independently distributed. The F-statistics and R-squared are similar to the standard OLS estimations. With the concern about outliers, the least-absolute value models (MAD models) were also performed to estimate the medians. Since the results of both techniques are similar, the result of MAD models are therefore not presented.

MLP models estimate the cross-sectional time series data. The MLP model provides the random-effects estimator, which counts for both the individual-specific effects and time-specific effects. The panel-data model has been used to resolve or reduce the magnitude of a potential econometric problem that omitted variables are correlated with explanatory variables. More importantly, the MLP model uses both the within and the between information and captures the over-time information. 
William Davidson Institute Working Paper 395

Mundlak (1978) argues that the individual effects should be always treated as random. Moreover, ranging from 287 firms in 1994 to 826 firms in 1998, the unbalanced panel dataset is wide and longitudinal. In addition, the results of Baltagi-Li LM tests also support the assumption of random effects. The maximum log likelihood estimation of the MLP model is consistent and asymptotically efficient for my data 22 . Therefore, the following model is estimated

$$
y_{i t}=\alpha+x_{i t} \beta+v_{i}+\varepsilon_{i t}
$$

by maximizing the log likelihood of the $i$ th unit

$l_{i}=-\frac{1}{2}\left\{\frac{1}{\sigma_{e}^{2}}\left[\sum_{t=1}^{T_{i}}\left(y_{i t}-x_{i t} \beta\right)^{2}-\frac{\sigma_{u}^{2}}{T_{i} \sigma_{u}^{2}+\sigma_{e}^{2}}\left(\sum_{t=1}^{T_{i}}\left(y_{i t}-x_{i t} \beta\right)\right)^{2}\right]+\ln \left(T_{i} \frac{\sigma_{u}^{2}}{\sigma_{e}^{2}}+1\right)+T_{i} \ln \left(2 \pi \sigma_{e}^{2}\right)\right\}$

This paper mainly reports the results of the polynominal forms of independent variables. 23 The polynomial regressions are under the assumption that the relationship between state shareholding and corporate value is non-linear. The piecewise regressions were also performed and the results support the conclusion of this paper. For conciseness, they are not reported here.

The investigation starts from the univariate analysis which is free of the multicollinearity problem. Then it is control for identified spurious effects.

\section{B. Control variables}

To deal with the possibility that a variety of factors can jointly affect state ownership and corporate value and thus induce a spurious correlation between them, multivariate analyses are performed with controlling for a set of factors. Based on both the conventions in the corporate finance literature and the Chinese institutional backgrounds, this paper uses corporate size, asset structure, capital structure, firm age, as well as stock exchange, industrial sector and year dummies as the control variables. 


\section{William Davidson Institute Working Paper 395}

Table VI presents the definitions and the predicated signs of the variables used in this paper.

\section{B.1 Shareholding structures}

The shareholding structures influence both the distributions of government shareholding and corporate value. Four ownership control variables are chosen. Gomes and Novaes (1999) argue that in the presence of a second large owner, the actions of the controlling shareholder are monitored and this contains tunneling of corporate wealth. It predicts that the second largest owner is associated with a high market value. The dummy variable of Second is defined as whether or not there is a second shareholder having more than $10 \%$ stake in a firm. As for the enterprises without government shareholding, whether a large shareholder exists influences corporate governance and value. The dummy variable of LargePrivate is therefore created by whether there is a major non-government shareholder in the private enterprise. The Herfindhal index of the ten largest shareholders is a proxy of the shareholding concentration. It is used to control for the shareholding structures when comparing mixed enterprises with private enterprises by the dummy variable regressions. However, the Herfindahal index is seriously correlated to the equity stakes of the government. It has to be left out when state shareholding is an explanatory variable. Morck et al (1988) show the influence of managerial ownership on Tobin's Q. The fourth ownership-related control variable Manager is used to control for the shares held by the top management team.

\section{B.2 Size}

With regard to economic fundamentals, large-sized firms may have scale economies and better access to bank credits, which could improve corporate profitability (Chhibber and Majumdar 1999). On the other hand, large enterprises 


\section{William Davidson Institute Working Paper 395}

often have the government having a relatively high equity stake. Size also has an effect on the relation between state shareholding and corporate value. It needs to be controlled in the regression models.

\section{B.3 Tangibility}

The asset structure or the assets' tangibility influences firms' growth and corporate valuation. The Chinese government tends to hold larger percentages in the enterprises with a higher proportion of fixed assets. Meanwhile, corporate value of these companies is affected by their capital intensity. This may introduce a spurious effect on the correlation between state shareholding and corporate value. The tangibility ratio also helps to identify the growth potential of a company. 24 Tangibility is approximated by the fixed asset ratio that is calculated as the net fixed assets divided by total assets 25 .

\section{B.4 Leverage}

Another basic firm characteristic is capital structure. Titman and Wessels (1988) and Rajan and Zingales (1995) find that capital structure is correlated to ROA and market-to-book value. Kornai (1980) argues that the enterprises with state ownership have a soft budget constraint - they can borrow as much as they want without the worry of financial distress or bankruptcy. The cost of financial distress is therefore relatively low in China where soft budget constraints exist. The static tradeoff story of debts between tax shield and cost of financial distress is perhaps dominated by the benefits of debts in the PLCs. This predicates that corporate value is a positive function of gearing ratio of debts. The gearing ratio is measured as total liabilities over total asset in the reported tables. Other forms of leverage ratios were tested and similar results were obtained.

\section{B.5 Age}


William Davidson Institute Working Paper 395

A firm has its life cycle and the age of a firm is related to corporate profitability and market value. Meanwhile, firm ages are correlated to state shareholding. Old firms have higher state shareholding, which is consistent with the path dependence theory. Firm age needs to be controlled.

\section{B.6 Industries}

Both state shareholding and corporate value vary across industries. The true relationship between state shareholding and corporate value can be hidden by industry-specific shocks. Schmalensee (1985) shows that accounting rates at the business-unit level are strongly influenced by industries and Wernerfelt and Montgomery (1988) find that industrial effects account for the majority of the explained variance of Tobin's Q. It is mandatory to control for industrial shocks. There are two kinds of industrial classifications for Chinese PLCs. One is the fiveindustry code: manufacturing, trade, utility, real estate and conglomerates. It is used by most existing studies on Chinese PLCs (for example, Xu and Wang 1999), but the industry effects cannot be well captured by this over-simplified industry classification (Chen and Jiang 2000). The other is a two digit standard industrial classification as 21-industry-code. Adopting this two-digit industrial classification is a significant technical feature of this study. The coefficients of the 21 industrial dummies are not reported in the tables, because they make the tables cumbersome but does not add value for the empirical conclusions.

\section{B.7 Stock exchange}

The data used in this paper is from companies listed on two stock exchangesShanghai Stock Exchange and Shenzhen Stock Exchange. Due to historical and geographic reasons, the distributions of state shareholding between two stock 


\section{William Davidson Institute Working Paper 395}

exchanges are not exactly the same. The dummy of Exchange is the proxy of the stock-exchange specific noise. It has value 1, if the firm is traded in Shanghai.

\section{B.8 Time dummies}

Year dummies are also used, because they can capture the rapid institutional changes and macroeconomic shocks in different years.

\section{Robustness tests}

In order to be cautious about the proxies of corporate value, other measures of corporate performance were tested, including Excess Value, Return on Sales, Return on Equity, Net Margin and Return on Capital Employed. The results support the findings based on Tobin's Q and ROA.

Specifying the model with control variables carefully follows the corporate finance literature. Further, more sensitivity tests are performed by adjusting the set of control variables; for example, by adding the sales-growth ratio and removing the tangibility ratio. The results are consistent with the reported tables. This study also considered the potential nonlinerity of the control variables and included their squared forms or cubic forms doing sensitivity analyses, but most of nonlinear forms of control variables tend to have insignificant coefficients. The signs for the independent variables remained the same with different sets of control variables.

The analyses crosschecked the potentially undue influence of outliers on the empirical results. Firstly, the median regressions performed are consistent with the results reported in the tables. Secondly, the results in the tables are robust if the Hadi dummies are added to capture the multiple outliers in the multivariate analysis. Thirdly, the DFITS test suggests that the regressions reported are generally fine. 


\section{William Davidson Institute Working Paper 395}

\section{Empirical Findings}

This section applies the econometric tools described in Section III to the three propositions from Section II. It compares corporate values of different groups of firms and then examines the continuous relationship between state shareholding and corporate value. The endogeneity issue is also verified in this section.

\section{A. O verall impacts}

The econometric investigations start by comparing the performance among companies with different sizes of state shareholding. The enterprises are classified into: 1) mixed enterprises (ME) and private enterprises (NSE 2 , 2) the enterprises whose largest shareholder is the government (SL) and those with the non-government shareholder as the largest shareholder (NSL); 3) the enterprises where the majority shareholder is the government (Smaj) and those with the non-government majority shareholder (NSmaj).

The so-called private enterprises on the stock market are actually the enterprises without state shares (NSEs). The owners of these enterprises include both institutions and families. The enterprises with state shareholding more than $0 \%$ but less than $100 \%$ are termed as the mixed enterprises (MEs). In a firm with some state assets, the managers may feel obliged to serve for the state interest in this communist country or, more realistically, they may use it as a shield of managerial agency costs. Moreover, if there are some shares of the state, the government sends its representatives to the board of directors. The government therefore somehow accesses the inside information. 27 Whether or not there is a government shareholder decides whether or not the government can influence the actions of the managers. Table VII finds that NSE significantly perform better than ME. The mean of the Q in 
William Davidson Institute Working Paper 395

NSEs is $19 \%$ higher than that in MEs, and ROA 18\% higher. This supports Hypothesis 1 in Section II that the firms without partial government ownership perform worse.

Another way to examine the overall influence of the government shareholder is to categorize the firms into those with the government as the largest shareholder and those with a non-government shareholder as the largest shareholder. The shareholder holding the largest stake is often the controlling shareholder, as there are few instances of collusion of other shareholders to counter the largest shareholder in China. 28 Table VII finds that the enterprises which have the government as the largest shareholder have a significantly higher value and profitability than those where a nongovernment shareholder holds the largest share of equity. If the government is the largest shareholder, Tobin's Q decreases $14 \%$ and ROA decreases $12 \%$.

This paper further groups firms by whether the majority shareholder is the government. Holding more than $50 \%$, the majority shareholder has the absolute control. The impact of other shareholders on corporate value is significantly reduced. Table VII finds that $\mathrm{Q}$ is 2.5 and ROA $5.4 \%$ with the majority government shareholder, while Q 3.0 and ROA 7.4\% where the majority shareholder is not the government. This is consistent with hypothesis 2 which states that firms under the control of the government shareholder perform worse.

There is certainly a concern that state shareholding and corporate value of the firms may be correlated through other factors. Table VII also compares corporate features of the firms. It finds that corporate characteristics vary according to the existence and influence of the government shareholder. Thus taking the different types of enterprises as dummy variables, multivariate regression analyses are requested to perform. 


\section{William Davidson Institute Working Paper 395}

The robust OLS and MLP multivariate regressions are presented in Table VIII. This table confirms that the enterprises without a government shareholder perform better than the enterprises with a government shareholder, and that the enterprises in which the government is the largest shareholder perform better than those in which a non-government entity is the largest shareholder. 29

The enterprises with a majority shareholder have highly concentrated shareholding structure and thus it has to be regressed without the control variable of Herfindhal in order to prevent the serious multi-collinearity problem. It is also found that the enterprises with a non-government majority shareholder are valued higher than enterprises with the government as the majority shareholder. This result, which is consisted with those presented in Table VIII, is not reported in the tables due to spaces.

Tables VII and VIII jointly approve Hypothesis 1 and 2. With regard to corporate value, state shareholding does matter and the government shareholding is,

on the whole, detrimental. With the first large sample of mixed enterprises $\frac{30}{\text {, this }}$ paper finds that private enterprises perform better than mixed enterprises. This conclusion is consistent with the empirical finding of Boardman and Vining (1989) and consolidates this stream of literature with a large sample of mixed enterprises. Further, this finding corroborates the dynamic privatization studies, to some extent $\frac{31}{\text {. }}$.

Table VIII also shows the impacts of other corporate features on corporate characteristics, which is discussed in Section V.C.

\section{B. U -shaped relationship}

To examine Hypothesis 3 that corporate value is a negative linear function of the voting rights of the government shareholder, this study regresses corporate value 


\section{William Davidson Institute Working Paper 395}

on the simple form of state shareholding in mixed enterprises. However, whether in the univariate or the multivariate analysis, there is not a significant relationship between corporate value and the simple form of state shareholding. The followings are the equations on the finding with the simple form of State in the multivariate analysis.

$$
\begin{aligned}
& Q_{i t}=8.490+0.187 * \text { State }_{i t}+0.171 * \text { Second }_{i t}+0.506 * \text { LargePrivate }_{i t}+1.232 * \text { Manager }_{i t}-0.638 * \text { Size }_{i t} \\
& \begin{array}{lllll}
(0.000) & (0.169) & (0.011) & (0.000) & (0.665)
\end{array} \\
& -0.436 * \text { Tangible }{ }_{i t}-1.383^{*} \text { Gear }_{i t}-0.005^{*} \text { Age }_{i t}-0.115^{*} \text { Exchange }_{i t}+\text { Industries }_{i t}+\text { Years }_{i t}+v_{i}+\varepsilon_{i t} \\
& \begin{array}{llll}
(0.040) & (0.000) & (0.012) & (0.096)
\end{array} \\
& \text { LR chi2 }=422.29, \quad \text { Prob }>\text { chi } 2=0.000, \quad \text { P-values in parenthesis. } \\
& \text { (1) }
\end{aligned}
$$

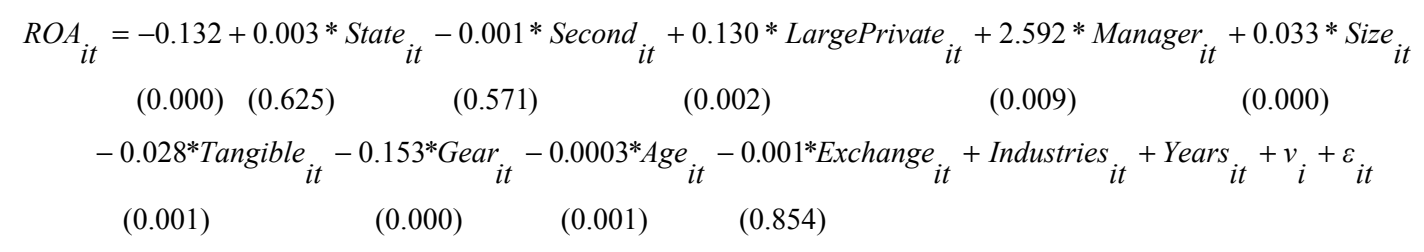

$$
\begin{aligned}
& \text { LR chi2 }=799.20, \quad \text { Prob }>\text { chi } 2=0.000, \quad \text { P-values in parenthesis } .
\end{aligned}
$$

The coefficients of State in equation 1 and 2 are not significant. Hypothesis 3 is therefore rejected. The government shareholder is not linearly incrementally detrimental with increase in state shareholding from small to large. The impact of government shareholding in the Chinese context is not fully consistent with the literature of state ownership.

However, Table V with descriptive statistics suggests some pattern for the relationship between state shareholding and corporate value. Hence, the paper further examines the continuous relationship between these two variables using spline regressions. It was found that both $\mathrm{Q}$ and ROA significantly decrease till a certain threshold and then significantly increase with the increased size of state 


\section{William Davidson Institute Working Paper 395}

shareholdings. However, the results depend on the choice of the spline knots. The relationship is therefore examined and reported with the polynomial regressions.

Table IX shows that there is a highly significant non-monotonic relationship between state shareholding and corporate value.

The multivariate MLP estimated equations are written down as follows:

$$
\begin{aligned}
Q_{i t}= & 8.674-1.367 * \text { State }_{i t}+2.318 * \text { State }_{i t}{ }_{i t}+0.188 * \text { Second }_{i t}+0.426 * \text { LargePrivate }_{i t}+1.475 * \text { Manager }_{i t}-0.654 * \text { Size }_{i t} \\
& (0.000)(0.001) \\
& -0.474 * \text { Tangible }_{i t}-1.389 * \text { Gear }_{i t}-0.005 * \text { Age }_{i t}-0.102 * \text { Exchange }_{i t}+\text { Industries }_{i t}+\text { Years }_{i t}+v_{i}+\varepsilon_{i t} \\
& (0.025) \\
(0.000) & (0.023)
\end{aligned}
$$

LR chi2 $=438.14, \quad$ Prob $>$ chi $2=0.000, \quad$ P-values in parenthesis.

$$
\begin{aligned}
& R_{i t}=-0.120-0.039 * \text { State }_{i t}+0.048 * \text { State }^{2}{ }_{i t}-0.003 * \text { Second }_{i t}+0.013 * \text { LargePrivate }_{i t}+0.298 * \text { Manager }_{\text {it }}+0.014 * \text { Size }_{\text {it }} \\
& \begin{array}{llllll}
(0.000) & (0.018) & (0.039) & (0.265) & (0.006) & (0.018)
\end{array} \\
& -0.033^{*} \text { Tangible }_{i t}-0.169^{*} \text { Gear }_{i t}-0.0003^{*} \text { Age }_{i t}-0.001^{*} \text { Exchange }_{i t}+\text { Industries }_{i t}+\text { Years }_{i t}+v_{i}+\varepsilon_{i t} \\
& \begin{array}{llll}
(0.000) & (0.000) & (0.003) & (0.854)
\end{array}
\end{aligned}
$$

The coefficient of State is significantly negative and that of State $^{2}$ is significantly positive. This means the statistic relationship between state shareholding and corporate value looks like the following stimulated chart:

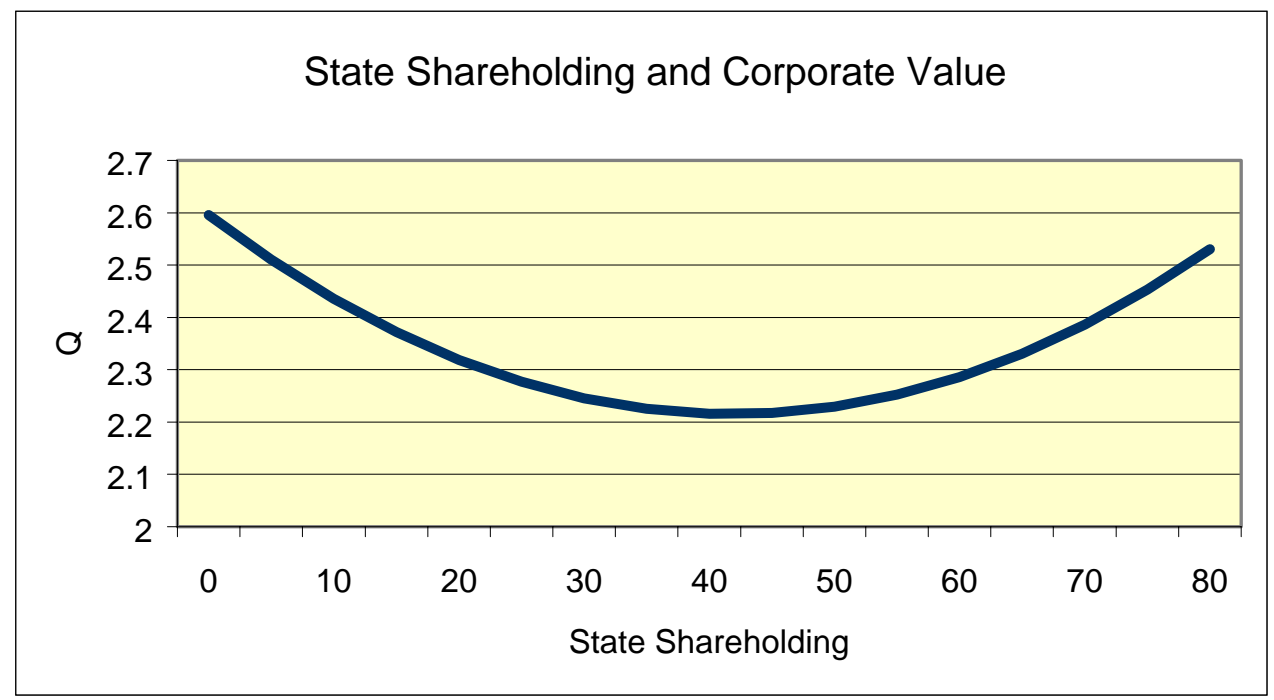




\section{William Davidson Institute Working Paper 395}

The firms are valued lower when the shareholding stake of the government is higher, but, after a certain threshold, corporate value increases with the size of state's shareholding stakes. Using a back-of-envelope calculation, it is found that the turning points are relatively stable in the $30 \sim 40 \%$ range of government shareholding, depending on the model specification. It is called a U-shaped pattern with a higher left end than the right end.

In contrast to the theory which suggested that state ownership leads to inefficiency, the actual impact of state shareholding on corporate value is profound. The negative relationship between state shareholding and corporate value before a certain threshold suggests that a small government shareholder is incrementally detrimental. The positive relationship between state shareholding and corporate value after a certain threshold suggests that a large government shareholder is incrementally beneficial.

\section{Endogeneity issue}

Section IV.B. finds that there is a U-shaped pattern between state shareholding and corporate value. The reason may be that the amount of state shares is the choice of the government based on corporate profitability and value. Does corporate value cause the distribution of state shareholding? This section discusses the endogeneity issue of the U-shaped finding and examines whether corporate value causes the distribution of state shareholding.

If there exists a certain causality from corporate value to state shareholding, it can happen through three channels. The first is IPOs or initial public offerings. The government shareholder may sell more shares in the enterprises that have higher profitability. This assumes that the government targets at raising revenue from selling 
William Davidson Institute Working Paper 395

state ownership in enterprises. If so, as the offer prices are normally strongly correlated to corporate profitability, the causality can run from profitability to the change of state shareholding in the initial public offering process. The second channel is SEOs or seasoned equity offerings. After the IPOs, the government may increase its shareholding based on the firm's profitability. The third channel is the market for partial stake transfer, since the government is forbidden from participation in the open market by law. The change of state shareholding in these three processes may be based on corporate value.

Timely-ordering is a necessary condition of causality. The paper further tests whether the past distribution of corporate profitability is correlated to the change of state shareholding stakes. The following equation was achieved.

$$
\text { StateChang } e=0.062-0.559 * R_{0} A_{-1}+\text { Industries }+\varepsilon
$$

$$
\text { F-statistics }=27.47 \quad R \text {-squared }=0.145 \quad P \text {-values in parenthesis. }
$$

The signs of $R O A_{-1}$ keep insignificant when the model specifications are changed with more control variables. Statistically, if there is no correlation, and hence there cannot be causality. That is, historical corporate performance does not cause the distribution of state shareholding.

It is consistent with the Chinese reality that liquidation of the government's equity stake in a company does not target at raising fiscal revenue $\frac{32}{3}$ The ideology of the communist party dominates the financial interest of the government in the IPOs. The goal of selling part of state ownership is aimed at restructuring enterprises 33 .

With regard to SEOs, the central government encourages its agents that directly hold state shares to maintain the former position in corporate control, but it does not allocate the sufficient budgets for the season equities. Therefore, the 
William Davidson Institute Working Paper 395

purchase of seasoned shares is decided not by corporate profitability, but by the budgetary constraints of the agents holding state shares. In practices, the controlling rights of the government shareholder are normally diluted during SEOs.

As for the block transfer of state shares, it is also targeted at enterprise restructuring. There are a number of cases wherein the government to grant its shares to strategic investors 3 . For example, the government gave for free its shares in Tianjin Meilun to Tianjin Taida Group Co. in 1997. Securities Times (2000) found that the state-shares transfers, including both grant transfers and negotiated transfers, usually aims at injection of new capital into the company and updating its technology rather than raising revenue for the government.

Thus corporate value does not cause the distribution of state shareholding. The significant non-monotonic relationship between state shareholding and corporate performance is therefore caused by the impacts derived from the equity stakes of the government. How does the government shareholder cause the U-shaped distribution of corporate value under different sizes of state shareholding?

\section{Interpretation and Further Findings}

With the intention to guide future theoretical work, this section provides an interpretation of this U-shaped finding. The empirical evidences on employees' welfare, board-member turnovers and government subsidies support this interpretation, to some extent.

\section{A. The grabbing hand-political interference}

Political interference tunnels out the wealth of the joint-stock company for the usage of the government. This damages the interests of other shareholders and the 
William Davidson Institute Working Paper 395

profitability of the firm. As a result, it predicts that mixed enterprises should be valued lower than private enterprises. In the context of a joint stock company, the possibility of political interference depends on the voting rights of the government shareholder as other shareholders oppose the grabbing hand of the government shareholder. Political interference increases with the sizes of state shareholding. This is consistent with the first part of the U-shape-corporate value decreases with state shareholding until a certain threshold.

However, at some point where the stake of the government shareholder is sufficiently large, increased voting rights of the government shareholder stop increasing the probability and magnitude of political interference. Other things being equal, it would expect that the influence of politicians on the firm where the government shareholder owns $51 \%$ is the same as that on the firm where the government owns $85 \%$. After the threshold of a controlling stake 3 political interference reaches the maximum. Furthermore, the government shareholder has no rationale to tunnel more corporate wealth from the firms it holds $85 \%$ than from the firms it holds $51 \%$, if these two firms are identical. Otherwise, it works against the financial interests of the government shareholder. This implies that, after a certain threshold, the magnitude of political interference stops increasing with increased cash flow rights of the government shareholder. Therefore, in terms of political interference, corporate value decreases with increased state shareholding under a certain threshold and then their continuous relationship becomes a constant. Assigning the threshold as $\theta_{1}$, there are $\frac{\partial B}{\partial a}>0$ and $\frac{\partial V}{\partial B}<0$ if $a<\theta_{1}$ where $V$ is corporate value, $B$ is the private benefits from political interference and $a$ is the 
fraction of voting rights. When $a>\theta_{1}, \frac{\partial B}{\partial a}=0$, which partly explains why the coefficient of State in equation numbered 3 is not significant.

\section{B. A helping hand-corporate governance}

The government shareholder can be helpful. With its financial interests being the cash flow rights of the company, the government shareholder may provide corporate governance and prevent from managerial entrenchment.

Corporate governance is to control managerial agency cost under the separation of ownership and management (Tian 1999). Corporate governance is costly, but it adds value to the firm. If the voting rights of the government are small, it is difficult for the government to control the manager. More importantly, when the cash flow rights are small, the government shareholder has low incentives to provide the costly monitoring of the managers. However, when the part of the increased corporate value apportioning to the government shareholder overweigh the monitoring cost, the government shareholder gets the incentive to provide corporate governance. This incentive increases with the sizes of shareholding stakes. If denoting $G$ as the cost of corporate governance, there are $\frac{\partial G}{\partial a}>0$ and $\frac{\partial V}{\partial G}>0$ when $a>\theta_{2} ; \frac{\partial G}{\partial a}=0$ when $a<\theta_{2}$

\section{A helping hand-government's partiality}

Regarding the incentives of corporate governance, there is not much difference between the government shareholder and other shareholders. The particularity of the government shareholder is the capability to provide a wide range of preferential treatment. It includes biased regulations when the government is a 


\section{William Davidson Institute Working Paper 395}

regulator, a preferential loan when the government is a creditor, a large order of products when the government is a consumer or a discounted sale of production factors when the government is a producer.

However, the partiality is not cost-free. It is at the expense of the financial interest or even political interest of the government. Therefore, the government has no incentives to provide the costly partiality in the firm where its cash flow rights are small. The allocation of partialities is correlated to the cash flow rights of the government. There are $\frac{\partial S}{\partial a}>0$ and $\frac{\partial V}{\partial S}>0$ when $a>\theta_{3}$, where $S$ denotes the cost of government partiality; $\frac{\partial V}{\partial a}=0$ when $a<\theta_{3}$.

Regarding the government partiality, a large government shareholder is helpful and corporate value will increase with the share stake of the government after a certain threshold.

\section{Synergy of the grabbing hand and the helping hands}

Based on the behaviors of political predation, corporate governance and preferential treatment, the utility function of the government shareholder is as follows.

$$
U=a * V+B-G-S
$$

Subject to :

$$
\begin{aligned}
& 0 \leq a \leq 1 \\
& V=V_{0}+V_{G}+V_{S}-V_{B}
\end{aligned}
$$

where $V_{0}$ is corporate value independent of $a, V_{G}$ is value changed by $G, V_{S}$ by $S, V_{B}$ by $B$.

Therefore

Set $\varphi<\theta_{2}$ and $\varphi<\theta_{3}$, when $\varphi<\theta_{1}, \quad$ get $\frac{\partial V}{\partial a}<0$;

Set $\psi>\theta_{2}$ and $\psi>\theta_{3}$, when $\psi>\theta_{1}, \quad$ get $\frac{\partial V}{\partial a}>0$;

where $\varphi<\psi$. 


\section{William Davidson Institute Working Paper 395}

Thus the relationship between the share stakes of the government shareholder ${ }^{37}$ and corporate value is negative till a certain threshold and positive after a threshold. It explains the U-shaped finding.

The role of the government shareholder is the aggregated impact of its different goals - political interests and financial interests. Its political interests of tunneling and reallocation of resources are pursued with the detrimental political interference. Its financial interests that is cash flow rights in the firm are pursued with the benevolent governance and partiality. When it is a small shareholder, the government does not provide corporate governance or preferential treatment, but political intervention increases with the voting rights of the government shareholder. This explains that the value of the firm is lower with a larger share stake of the government until a certain threshold in Table VIII. When the government becomes a large shareholder, the government shareholder incrementally provides corporate governance and preferential treatment and these improve corporate value, meanwhile the magnitude of political predation stops increasing 38 . This interprets that the value of firms decreases with a larger stake of government shareholding until a certain threshold in Table VIII.

\section{E. Empirical evidence}

In order to empirically investigate the above interpretation, this paper makes an attempt to directly examine the governmental behaviors. However, due to the limitation of my dataset, the proxies of political interference, state-based corporate governance and government's partiality are controversial.

The Chinese government under the control of the communist party is defined itself as the representative of the workers. The public choice school also suggests that, as a special interest group, the labor unions influence the politicians. Therefore, 


\section{William Davidson Institute Working Paper 395}

the government shareholder may encourage the managers to spend more on employees' welfare, which serves its political interest. The accountancy item of employees welfare is used to approximate the magnitude of political interference. According to China's GAAP, this item mainly records the expenditure on medical and health cares of the employees in the firm. Government partiality is approximated by the accountancy item of government subsidies. This records the explicit subsidies given by the government, including tax rebates. I then use the frequency of boardmember turnovers to approximate the degree of managerial entrenchment problem and therefore the quality of corporate governance.

Table X presents the results of the robusts estimation of the simple State form and its piecewise forms 39 . It finds that the expenditure of employees' welfare increases with a larger share stake of the government before $50 \%$. After the $50 \%$, the relationship between state shareholding rights and employee welfare is not significant. The government has no incentive to increase the probability and magnitude of political predation after this absolute controlling threshold.

After the threshold of $50 \%$, the board-turnover significantly increases with state shareholding. This is consistent with the argument that corporate governance gets strengthened when the financial interest of the government increases. In the range between $0 \%$ to $30 \%$ and $30 \%$ to $50 \%$, it was notified that state shareholding is not correlated to board turnover. This finding is supportive in that the magnitude of the managerial entrenchment problem is a negative function of the state shareholding rights, when the government stays in absolute control.

When state shareholding is over $50 \%$, there is a significant positive relationship between the size of government subsidies and the sizes of the state shareholding stakes. When the government is a substantially large shareholder, the 


\section{William Davidson Institute Working Paper 395}

enterprises are given more subsidies. The insignificant relationship when the government is a small shareholder shows that the government is reluctant to subsidize enterprises if its cash flow rights are low.

In summary, the U-shaped pattern is empirically based on the interaction of political interference, corporate governance and government partiality.

\section{Conclusion}

This paper examines the shareholding structure and the role of the government shareholder with the firms listed on China's stock market. It shows that the government is the largest shareholder of $43.9 \%$ of firms listed on China's stock market. $50 \%$ is taken as the threshold for the absolute control, the government absolutely controls $31.4 \%$ Chinese PLCs. This paper therefore suggests that state shareholding is a main feature of Chinese firms and that hence the key to understanding Chinese firms is through the role of the government shareholder.

Using a panel database of the firms traded on Shanghai and Shenzhen stock exchanges from 1994 to 1998, this paper finds that firms without state shareholding perform significantly better than those with state shareholding, firms where a nongovernment shareholder holds the largest stake perform better than those with the government as the largest shareholder, and firms having a non-government majority shareholder perform better than those having the government majority shareholder. This implies that the overall impact of the government shareholder is detrimental for

corporate value. Therefore, with the first large sample of mixed enterprises $\frac{40}{4}$, this study consolidates the literature on state ownership and corporate performance. 


\section{William Davidson Institute Working Paper 395}

However, the detrimental impact of state shareholding is not monotonic. The companies with higher voting rights of the government shareholder are not necessarily always valued lower. This paper finds a U-shaped relationship between the sizes of the government equity holding and corporate value with a higher left end than the right end. When the government is a small shareholder, the relationship between increased state shareholding and corporate performance is negative; however, this relationship becomes positive when the government is a large shareholder. That is, the government shareholder is incrementally detrimental with a small holding stake, but incrementally benevolent with a large holding stake.

This paper argues that this U-shape is caused by the behavior of the government shareholder that is rooted in its cash flow rights and voting rights. The government shareholder maximizes its overall interests with political interference, corporate governance and government partiality. The grabbing hand induces a lower corporate value with a larger stake of state shareholding before a certain threshold, but the government also provides helping hands if its financial interests become sufficiently large. This interpretation gets supports from the available empirical evidence.

This paper may have a certain policy implications. If only corporate value is taken into consideration, the finding of the overall detrimental impact of the government shareholder supports privatization. The U-shaped relationship between state shareholding and corporate value suggests full privatization and one-shot sale of state shares at the firm-level. Meanwhile, the optimal business strategy in acquiring state shares is to buy out state shares at one shot. The bidder of state shares should request that the government fully retreat from the firm. 


\section{William Davidson Institute Working Paper 395}

Documenting the features of China's PLCs, this paper proposes a new topic in financial institutions as the role of the government shareholder. This contributes to the governance and ownership literature and intends to stimulate theoretical research. Hart (1995) suggests that "analyzing public versus private ownership in incomplete contracting terms... is a challenging but fascinating task for future research". This paper tries to take a new step. 


\section{William Davidson Institute Working Paper 395}

\section{Reference:}

Boardman, Anthony E and Aidan R Vining, 1989. Ownership and performance in competitive environments: A comparison of the performance of private, mixed and State-owned enterprises. Journal of Law and Economics 32: 1-33.

Booth Laurence, Varouj Aivazian, Asli Demirguc-Kunt, Vojislav Maksimovic, 2000. Capital Structures in Developing Countries. Journal of Finance, forthcoming.

Boycko, Maxim, Andrei Shleifer, and Robert W. Vishny, 1996. A Theory of Privatisation. Economic Journal, 106(435): 309-19.

Buffett, Warren, 1998. The Essays of Warren Buffett: Lessons for Corporate America. Edited by Lawrence A Cunningham.

Chen, Xiao and Dong Jiang, 2000. The Role of Legal Person Shares and Trading Shares in Corporate Governance. Working Paper, Tshinghua University.

Chen, Gongmeng, Michael Firth and Oliver Rui, 2000. Have China's Enterprise Reforms Led to Improved Efficiency and Profitability for Privatized SOEs? Working Paper, Hong Kong Polytechnic University.

Chhibber, Pradeep K and Sumit Majumdar, 1999. Foreign ownership and profitability: Property rights, control and the performance of firms in Indian industry. Journal of Law and Economics 42:209-238.

Chung, Kee H and Stephen Pruitt, 1994. A simple approximation of Tobin's q. Financial Management 23(3): 70-74.

Claessens, Stijn, Simon Djankov, and Larry H. P. Lang, 2000. The Separation of Ownership and Control in East Asian Corporations. Journal of Financial Economics, 58(1-2): 81-112.

Cooper, Ian and Evi Kaplanis, 1994. Home Bias in Equity Portfolios, Inflation Hedging, and International Capital Market Equilibrium. Review of Financial Studies 7(1): 45-60.

Demsetz, Harold and Kenneth Lehn, 1985. The structure of corporate ownership: causes and consequences. Journal of Political Economy 93:1155-77.

Eckel, Catherine C and Vermaelen Theo, 1986. Internal Regulation: The Effects of Government Ownership on the Value of the Firm. Journal of Law and Economics 29: 381-403.

Faccio, Mara and Larry H. P. Lang, 2000. The Separation of Ownership and Control: An Analysis of Ultimate Ownership in Western European Corporations. Working Paper, Social Science Research Network.

Fama, Eugene F and Kenneth French, 1995. Size and Book-to-Market Factors in Earnings and Returns. Journal of Finance. 50(1): 131-155.

Franks, Julian and Colin Mayer, 2000. Ownership and Control of German Corporations. Review of Financial Studies, forthcoming.

Gomes, Armando and Walter Novaes, 1999. Multiple Large Shareholders in Corporate Governance. Working Papers, Wharton School Rodney L. White Center for Financial Research.

Gorton, Gary and Frank A. Schmid, 2000. Universal Banking and the Performance of German Firms. Journal of Financial Economics 58(1-2): 29-80. 


\section{William Davidson Institute Working Paper 395}

Hall, Marshall and Leonard Weiss, 1967. Firm Size and Profitability. Review of Economics and Statistics 49(3): 319-331.

Hart, Oliver, 1995. Firms, Contacts, and Financial Structure. Oxford: Oxford University Press.

Jensen Michael C. and William H. Meckling, 1976. Theory of the Firm: Managerial Behavior, Agency Costs and Ownership Structure. Journal of Financial Economics 3:305-360.

Kang, Jun Koo and Anil Shivadasani, 1995. Firm Performance, Corporate Governance and Top Executive Turnover in Japan. Journal of Financial Economics, 38:29-58.

Kay, J. A. and D. J. Thompson, 1986. Privatisation: A Policy in Search of A Rationale. Economic Journal, 96(381): 18-32.

Kole, Stacey R and Harold J Mulherin, 1997. The Government as A Shareholder: A Case from the United States. Journal of Law and Economics 40(1):1-22.

Kornai, Janos, 1980. The Economics of Shortage. Amsterdam: North-Holland Press.

Kornai, Janos, 1992. The Socialist System: The Political Economy of Communism. Princeton, NJ: Princeton University Press.

La Porta, Rafael and Florencio, Lopez-de-Silanes, Andrei Shleifer, Robert Vishny, 1998. Law and Finance. Journal of Political Economy 106: 1113-1155.

La Porta, Rafael and Florencio, Lopez-de-Silanes, Andrei Shleifer 1999. Corporate Ownership around the World. Journal of Finance 54(2): 471-517.

La Porta, Rafael and Florencio, Lopez-de-Silanes, Andrei Shleifer, Robert Vishny, 1999. The Quality of the Government. Journal of Law, Economics and Organization 15(1):222-279.

La Porta, Rafael and Florencio, Lopez-de-Silanes, Andrei Shleifer, Robert Vishny, 2000. Investor Protection and Corporate Governance. Journal of Financial Economics, 58: 3-27.

Lindenberg, Eric B. and Stephen Ross, 1981. Tobin's q ratio and industrial organization. Journal of Business: 51:1-31.

McConnell, John J and Henri Servaes, 1990. Additional evidence on equity ownership and corporate value. Journal of Financial Economics 27: 595-612.

Megginson, William L., Robert C. Nash, and Matthias Van Randenborgh, 1994. The financial and operating performance of newly privatized firms: An international empirical analysis. Journal of Finance 49, 403-452.

Megginson, William L., Jeffery M Netter, 2000. From State to Market: A Survey of Empirical Studies on Privatization. Working Paper, The University of Oklahoma.

Milton, Friedman, 1953. Essays in positive economics. Chicago: University of Chicago Press.

Mises, Ludwig von, 1951. Socialism: An Economic and Sociological Analysis. Liberty Classics. Cambridge, MA: MIT Press.

Morck Randall, Andrei Shleifer and Robert W Vishny, 1988. Management ownership and market valuation: An empirical analysis. Journal of Financial Economics 20:293-316.

Moulton, Brent R, 1986. Random Group Effects and the Precision of Regression Estimates. Journal of Econometrics 32(3):385-397. 


\section{William Davidson Institute Working Paper 395}

Mundlak, Yair, 1978. On the Pooling of Time Series and Cross Section Data. Econometrica 46(1): 6985.

The Organization for Economic Co-operation and Development (OECD), 2000. Reforming China's Enterprises. Paris: OECD Press.

Perfect, Steven B., and Kenneth Wiles, 1994. Alternative constructions of Tobin's q: An empirical comparison. Journal of Empirical Finance 1: 313-341.

Prowse, Stephen D., 1998. The Structure of Corporate Ownership in Japan. Journal of Finance 47:1121-1140.

Qi Daqing, Woody Wu and Hua Zhang, 2000. Shareholding Structure and Corporate Performance of Partially Privatized Firms: Evidence from Listed Chinese Companies. Pacific-Basin Finance Journal, forthcoming.

Rajan, Raghuram G. and Luigi Zingales, 1995. What Do We Know about Capital Structure? Some Evidence from International Data. Journal of Finance 50(5):1421-1460.

Schmalensee, Richard, 1985. Do market differ much? American Economic Review 75:341-51.

Securities Times, 2000. http://www.p5w.net/company/200009/09/gsyj200009090110.html

Shin, Hyun-Han, and René M. Stulz, 1998. Are internal capital markets efficient? Quarterly Journal of Economics 113, 531-552.

Shleifer, Andrei and Robert W Vishny, 1994. Politicians and Firms. Quarterly Journal of Economics, 109(4):995-1025.

Shleifer, Andrei and Robert W Vishny, 1997, A survey of corporate governance, Journal of Finance 52(2): 737-783.

Shleifer, Andrei and Robert W Vishny, 1998, The Grabbing Hand: Government Pathologies and Their Cures. Cambridge, MA: Harvard University Press.

Stiglitz, Joseph E., 1994. Whither Socialism. Carmbridge, MA: The MIT Press.

Tian, Lihui George, 1999. A Theoretical Framework of Corporate Governance. Unpublished manuscript, London Business School.

Tian, Lihui George, 2000. Performance of mixed enterprises, agency cost and state shareholding. Unpublished manuscript, London Business School.

Titman, Sheridan and Roberto Wessels, 1988. The Determinants of Capital Structure Choice. Journal of Finance 43(1): 1-19.

Vickers, John and George Yarrow, 1988. Privatization: An Economic Analysis. Carmbridge, MA: The MIT Press

Vining, Aidan R. and Anthony E. Boardman, 1990. Ownership versus Competition: Efficiency in Public Enterprise. Public Choice 73:205-239.

Wernerfelt, Birger and Cynthia A. Montgomery, 1988. Tobin's q and the importance of focus in firm performance. American Economic Review 78:246-250.

Xu Xiaonian and Yan Wang, 1999, Ownership structure and corporate governance in Chinese stock companies. China Economic Review 10:75-98. 
Table I

\section{ChineseStock M arket}

This table presents the market capitalization over Chinese GDP, number of shareholders of the listed companies, number of listed companies, stock market indexes, turnover rates and price to earning ratios. The period covers from 1992 to 1998. The Chinese stock market is separated into Shanghai Stock Exchange and Shenxhen Stock

Exchange. The market capitalization and number of investors are the aggregated number from both the exchanges. The data sources are from Shanghai Stock Exchange,

Shenzhen Stock Exchange and China Securities Regulation Commission. Capitalization of Germany and UK equity markets are based on Bank of England, the factbook of London Stock Exchange. The P/E ratio is from Bloomberg system.

\begin{tabular}{|c|c|c|c|c|c|c|c|c|c|c|c|c|}
\hline & 1992 & 1993 & 1994 & 1995 & 1996 & 1997 & 1998 & & & 1998 & & \\
\hline & \multicolumn{6}{|c|}{ China } & China & Hong Kong & Japan & Germany & UK & USA(NYSE) \\
\hline Market Cap over GDP (\%) & 3.9 & 10.2 & 7.9 & 5.9 & 14.5 & 23.4 & 24.5 & 198 & 72 & 32 & 165 & - \\
\hline Investors (millions) & 2.2 & 7.8 & 10.6 & 12.4 & 23.1 & 33.3 & 39.1 & & & & & \\
\hline Newly Listed Companies & 39 & 130 & 108 & 32 & 207 & 215 & 106 & 32 & 57 & 68 & 233 & 228 \\
\hline Total Companies & 53 & 183 & 291 & 323 & 530 & 745 & 851 & 680 & 1,890 & 741 & 2921 & 3114 \\
\hline Shanghai & 29 & 106 & 171 & 188 & 293 & 383 & 438 & & & & & \\
\hline Shenzhen & 24 & 77 & 120 & 135 & 237 & 362 & 413 & & & & & \\
\hline Composite Index & & & & & & & & 10048 & 13842 & 4845 & 5882 & 9181 \\
\hline Shanghai & 780.4 & 833.8 & 647.9 & 555.3 & 917.0 & 1194.1 & 1146.7 & & & & & \\
\hline Shenzhen & 241.2 & 238.3 & 140.6 & 113.3 & 327.3 & 381.3 & 343.9 & & & & & \\
\hline Trading Values (US \$Billion) & 8.21 & 44.19 & 97.94 & 48.63 & 257.05 & 370.14 & 283.67 & 206.15 & 750.83 & 945.06 & 2887.89 & 7317.95 \\
\hline Turnover Rate (times) & & & & & & & & 62 & 34 & - & 47 & 70 \\
\hline Shanghai & - & 341 & 787 & 396 & 591 & 326 & 297 & & & & & \\
\hline Shenzhen & - & 213 & 472 & 180 & 902 & 466 & 283 & & & & & \\
\hline P/E Ratio & & & & & & & & 11.1 & 155.1 & 34.8 & 23.1 & 22.0 \\
\hline Shanghai & - & 42.5 & 23.5 & 15.7 & 31.3 & 39.9 & 34.4 & & & & & \\
\hline Shenzhen & - & 42.7 & 10.3 & 9.5 & 35.4 & 41.2 & 32.3 & & & & & \\
\hline
\end{tabular}


Table II

\section{Simplified Bal anceSheets}

This table presents the simplified aggregated balance sheet for the public listed companies on the Shanghai or Shenzhen Stock Exchange. It also presents the percentage of each item over the book value of total asset. The data on UK and Japan is the ratios of all firms from Rajan and Zingales (1995).

\begin{tabular}{|c|c|c|c|c|c|c|c|c|c|c|c|c|}
\hline \multirow[t]{2}{*}{ Accounting Items } & \multicolumn{2}{|c|}{1994} & \multicolumn{2}{|c|}{1995} & \multicolumn{2}{|c|}{1996} & \multicolumn{2}{|c|}{1997} & \multicolumn{2}{|c|}{1998} & \multirow{2}{*}{$\begin{array}{c}\text { UK } \\
\text { Ratio }\end{array}$} & \multirow{2}{*}{$\begin{array}{c}\text { Japan } \\
\text { Ratio }\end{array}$} \\
\hline & Value & Ratio & Value & Ratio & Value & Ratio & Value & Ratio & Value & Ratio & & \\
\hline Current Asset & 76.1 & 55.3 & 90.3 & 55.4 & 81.2 & 56.0 & 85.5 & 54.9 & 93.2 & 53.2 & 55 & 58 \\
\hline Fixed Asset & 40.9 & 29.7 & 51.1 & 31.3 & 47.6 & 32.8 & 53.9 & 34.6 & 63.5 & 36.3 & 41 & 29 \\
\hline Other Asset & 20.7 & 15.0 & 21.6 & 13.3 & 16.2 & 11.2 & 16.4 & 10.5 & 18.4 & 10.5 & 4 & 14.5 \\
\hline Total Asset & 137.7 & 100.0 & 163 & 100.0 & 144.9 & 100 & 155.8 & 100.0 & 175.1 & 100.0 & 100 & 100 \\
\hline Short-term Liability & 52.5 & 38.2 & 67.9 & 41.6 & 60 & 41.4 & 58.7 & 37.7 & 66.3 & 37.9 & 40 & 42 \\
\hline Long-term Liability & 12.1 & 8.8 & 17 & 10.4 & 17.6 & 12.2 & 19 & 12.2 & 19.1 & 10.9 & 18 & 25 \\
\hline Shareholders Equity & 67.3 & 48.9 & 73.9 & 45.3 & 67.1 & 46.3 & 77.5 & 49.8 & 88 & 50.3 & 42 & 34 \\
\hline
\end{tabular}


Table III

\section{Official Share Classes}

This table presents the official classification of common stock in Chinese public listed companies. CSRC represents China Securities Regulatory Commission. The numbers in the cells are calculated as the ratio of the corresponding class of shares over total shares. The first number is the cell is the mean, second in brackets is the standard deviation, third the minimum and fourth the maximum.

\begin{tabular}{|c|c|c|c|c|c|c|}
\hline CLASSES & DESCRIPTION & 1994 & 1995 & 1996 & 1997 & 1998 \\
\hline $\begin{array}{l}\text { State } \\
\text { shares }\end{array}$ & $\begin{array}{l}\text { Shares obtained by an institution, as a representative of the central government, on behalf of the State in exchange } \\
\text { for the capital contribution made by the State. The institution can be the central government itself, local } \\
\text { governments or wholly government-owned economic institutions. State shares are not available for trading at the } \\
\text { two stock exchanges, but are transferable to other domestic institutions, under the approval of CSRC. }\end{array}$ & $\begin{array}{c}0.334 \\
(0.271) \\
\\
0.000 \\
0.886\end{array}$ & $\begin{array}{c}0.381 \\
(0.244) \\
\\
0.000 \\
0.886\end{array}$ & $\begin{array}{c}0.354 \\
(0.254) \\
\\
0.000 \\
0.886\end{array}$ & $\begin{array}{c}0.316 \\
(0.264) \\
\\
0.000 \\
0.886\end{array}$ & $\begin{array}{c}0.275 \\
(0.268) \\
0.000 \\
0.886\end{array}$ \\
\hline $\begin{array}{l}\text { Legal- } \\
\text { person } \\
\text { shares }\end{array}$ & $\begin{array}{l}\text { The legal person shares are shares owned by domestic institutions. A legal person in China is defined as a non- } \\
\text { individual legal entity or institution. The Commercial Banking Law of China, which came into effect in } 1994 \text {, } \\
\text { prohibits commercial banks from underwriting, holding and trading shares. Legal person shares are not tradable } \\
\text { at the two stock exchanges, but can be transferred into other domestic institutions upon approval from the CSRC. }\end{array}$ & $\begin{array}{c}0.288 \\
(0.251) \\
\\
0.000 \\
0.883 \\
\end{array}$ & $\begin{array}{c}0.240 \\
(0.240) \\
\\
0.000 \\
0.928 \\
\end{array}$ & $\begin{array}{c}0.274 \\
(0.251) \\
\\
0.000 \\
0.883 \\
\end{array}$ & $\begin{array}{c}0.306 \\
(0.265) \\
\\
0.000 \\
0.913 \\
\end{array}$ & $\begin{array}{c}0.333 \\
(0.269) \\
0.000 \\
0.937 \\
\end{array}$ \\
\hline $\begin{array}{l}\text { Tradable- } \\
\text { A shares }\end{array}$ & $\begin{array}{l}\text { The tradable A-shares are held and traded mostly by domestic individuals and some by domestic institutions. } \\
\text { There is no restriction on the number of shares traded, but it is required that tradable A-shares should account for } \\
\text { no less than } 25 \% \text { of total outstanding shares when a company makes its IPO. There are the only shares allowed to } \\
\text { be publicly traded on Shanghai or Shenzhen Stock Exchange. }\end{array}$ & $\begin{array}{c}0.303 \\
(0.171) \\
\\
0.000 \\
1.000 \\
\end{array}$ & $\begin{array}{c}0.327 \\
(0.179) \\
\\
0.000 \\
1.000 \\
\end{array}$ & $\begin{array}{c}0.310 \\
(0.261) \\
\\
0.000 \\
1.000\end{array}$ & $\begin{array}{c}0.304 \\
(0.135) \\
\\
0.015 \\
1.000 \\
\end{array}$ & $\begin{array}{c}0.313 \\
(0.133) \\
0.000 \\
1.000 \\
\end{array}$ \\
\hline $\begin{array}{l}\text { Employee } \\
\text { shares }\end{array}$ & $\begin{array}{l}\text { Employee shares are offered to workers and managers of a PLC, usually at a substantial discount. Employee } \\
\text { shares are registered under the title of the labor union covering that company, which also represents shareholding } \\
\text { employees trying to exercise their rights. After a holding period of } 6 \text { to } 12 \text { months, the company may file with } \\
\text { CSRC to allow its employees to sell the shares in the open market, but the directors, supervisors and the general } \\
\text { managers may not transfer such shares during their term of office. }\end{array}$ & $\begin{array}{l}0.014 \\
(0.036) \\
0.000 \\
0.207\end{array}$ & $\begin{array}{l}0.010 \\
(0.041) \\
0.000 \\
0.334\end{array}$ & $\begin{array}{l}0.024 \\
(0.064) \\
0.000 \\
0.485\end{array}$ & $\begin{array}{l}0.031 \\
(0.069) \\
0.000 \\
0.485\end{array}$ & $\begin{array}{l}0.031 \\
(0.069) \\
0.000 \\
0.485\end{array}$ \\
\hline \begin{tabular}{l|} 
Shares \\
denominat \\
ed with \\
foreign \\
currency
\end{tabular} & $\begin{array}{l}\text { This group of shares includes B-shares on domestic stock exchanges, H-shares on the Hong Kong Stock } \\
\text { Exchange and N-shares on the New York Stock Exchange. B-shares are available exclusively to foreign investors } \\
\text { and some authorized domestic securities firms. The B-shares market is separated from the A-share market, with } \\
\text { SHSE B-shares are denominated in US dollars and SZSE B-shares are in Hong Kong dollar. H-shares and N- } \\
\text { shares carry the same rights and obligations as the A-shares and B-shares, but they can not be traded on domestic } \\
\text { stock exchanges. }\end{array}$ & $\begin{array}{c}0.062 \\
(0.130)\end{array}$ & $\begin{array}{c}0.057 \\
(0.120)\end{array}$ & $\begin{array}{c}0.047 \\
(0.112)\end{array}$ & $\begin{array}{c}0.039 \\
(0.105)\end{array}$ & $\begin{array}{c}0.049 \\
(0.121)\end{array}$ \\
\hline
\end{tabular}


Table IV

\section{Shareholding Structures of ChineseQuoted Firms}

Panel A: Proportion of Companies with a Single Shareholding in Excess of 10\%, 30\% and 50\%

This table summarizes the proportion of companies with a large shareholder. Companies are partitioned into those that have one shareholder owning at least $10 \%, 30 \%$ and $50 \%$ of the voting equity and the cases as the largest shareholder, respectively. It is based on the 1998 data for 826 companies. The data regards of firms in Hong Kong and Japan is from Claessens, Djankov and Lang (2000); UK and Germany from Faccio and Lang (2000).

\begin{tabular}{|c|c|c|c|c|c|c|c|c|}
\hline & Largest shareholder & $50 \%$ & $30 \%$ & $10 \%$ & \multicolumn{4}{|c|}{$10 \%$ Cut-off } \\
\hline & & & & China & $\begin{array}{l}\text { Hong } \\
\text { Kong }\end{array}$ & UK & Germany & apan \\
\hline Another Domestic Company & 39.2 & 10.5 & 27.3 & 41.2 & 23.9 & 0.9 & 1.2 & 5.3 \\
\hline Trust, Securities and Other Financial Companies & 10.9 & 0.8 & 2.5 & 4.4 & 7.1 & 32.6 & 10.4 & 38.5 \\
\hline Foreign & 5.1 & 0.0 & 3.1 & 6.2 & - & - & - & - \\
\hline Family & 0.0 & 0.0 & 0 & 0 & 64.7 & 33.8 & 71.6 & 13.1 \\
\hline State & 43.9 & 31.4 & 37.8 & 43.8 & 3.7 & 0.2 & 5.2 & 1.1 \\
\hline Others & 0.8 & 0 & 3.8 & 2.4 & 0 & 6.3 & 7.2 & 0 \\
\hline $\begin{array}{l}\text { Companies without a large shareholding greater } \\
\text { than } 10 \%, 30 \%, 50 \%\end{array}$ & & 57.2 & 25.4 & 2.1 & 0.6 & 26.2 & 4.40 & 42 \\
\hline Ratio of Cash Flow to Voting Rights & & & & 99.9 & 88.2 & 86.3 & 84.2 & 60.2 \\
\hline
\end{tabular}

\section{Panel B: Shareholding fractions of the largest 10 shareholders}

This table summarizes the average shareholding fractions of the largest 10 shareholders under the category of mixed enterprises, no-state-shareholding enterprises, enterprises with the government as the largest shareholder and enterprises with non-government as the largest shareholder. It shows the concentration of shareholding in Chinese quoted firms. The data is 826 firms in 1998 .

\begin{tabular}{|c|c|c|c|c|c|c|c|c|c|c|}
\hline & $1 \mathrm{st}$ & 2nd & 3rd & 4th & 5th & 6th & 7th & 8th & 9th & 10th \\
\hline Mixed Enterprises & 42.5 & 10.1 & 3.8 & 2.0 & 1.3 & 0.8 & 0.6 & 0.5 & 0.4 & 0.4 \\
\hline Private Enterprises & 41.5 & 11.7 & 4.8 & 2.6 & 1.5 & 0.9 & 0.7 & 0.5 & 0.4 & 0.4 \\
\hline Enterprises with a non-government largest shareholder & 40.1 & 12.3 & 5.0 & 2.7 & 1.6 & 0.9 & 0.7 & 0.5 & 0.4 & 0.4 \\
\hline Total & 42.1 & 10.7 & 4.2 & 2.2 & 1.4 & 0.9 & 0.6 & 0.5 & 0.4 & 0.4 \\
\hline
\end{tabular}


Table V

\section{CorporatePerformanceal ong the StateSharehol ding Spectrum}

This table reports the number of firms, the average Q and the average ROA under the $10 \%$-scaled percentile of the size of the state shareholding stakes from the 1994 to 1998. State shareholding is calculated as the State-owned -shares as a percentage of total common shares. ROA is calculated as net profit after tax over total assets. Q is calculated as the market value of equity and book value of debt over the asset value in order to approximate Tobin's Q. The table presents the mean values of Q and ROA.

\begin{tabular}{|c|c|c|c|c|c|c|c|c|c|c|c|c|c|c|c|c|c|c|}
\hline & \multicolumn{3}{|c|}{1994} & \multicolumn{3}{|c|}{1995} & \multicolumn{3}{|c|}{1996} & \multicolumn{3}{|c|}{1997} & \multicolumn{3}{|c|}{1998} & \multicolumn{3}{|c|}{ Total } \\
\hline State & $\begin{array}{l}\text { No of } \\
\text { Firms }\end{array}$ & $Q$ & $R O A$ & $\begin{array}{l}\text { No of } \\
\text { Firms }\end{array}$ & $Q$ & $R O A$ & $\begin{array}{l}\text { No of } \\
\text { Firms }\end{array}$ & $Q$ & $R O A$ & $\begin{array}{l}\text { No of } \\
\text { Firms }\end{array}$ & $Q$ & $R O A$ & $\begin{array}{l}\text { No of } \\
\text { Firms }\end{array}$ & $\mathrm{Q}$ & $R O A$ & $\begin{array}{l}\text { No of } \\
\text { Firms }\end{array}$ & $Q$ & $R O A$ \\
\hline 0 & 80 & 2.677 & 0.084 & 53 & 1.973 & 0.054 & 116 & 2.779 & 0.055 & 216 & 3.290 & 0.065 & 313 & 2.977 & 0.051 & 778 & 2.935 & 0.059 \\
\hline 0.1 & 15 & 2.004 & 0.073 & 15 & 1.764 & 0.040 & 22 & 2.551 & 0.033 & 30 & 3.166 & 0.041 & 39 & 2.943 & 0.030 & 121 & 2.665 & 0.040 \\
\hline 0.2 & 9 & 1.757 & 0.050 & 11 & 1.491 & 0.044 & 18 & 2.721 & 0.039 & 29 & 2.863 & 0.048 & 35 & 2.889 & 0.034 & 102 & 2.601 & 0.041 \\
\hline 0.3 & 17 & 1.741 & 0.058 & 24 & 1.456 & 0.042 & 53 & 2.312 & 0.046 & 64 & 2.539 & 0.050 & 70 & 2.452 & 0.022 & 228 & 2.286 & 0.040 \\
\hline 0.4 & 37 & 1.646 & 0.077 & 44 & 1.485 & 0.053 & 61 & 2.559 & 0.059 & 78 & 2.811 & 0.051 & 81 & 2.631 & 0.041 & 301 & 2.374 & 0.053 \\
\hline 0.5 & 37 & 1.848 & 0.059 & 54 & 1.586 & 0.038 & 64 & 2.486 & 0.050 & 77 & 2.869 & 0.058 & 79 & 2.528 & 0.040 & 311 & 2.360 & 0.048 \\
\hline 0.6 & 28 & 1.937 & 0.066 & 45 & 1.790 & 0.056 & 77 & 2.747 & 0.060 & 87 & 2.728 & 0.049 & 82 & 2.543 & 0.036 & 319 & 2.483 & 0.051 \\
\hline 0.7 & 34 & 2.549 & 0.070 & 38 & 1.694 & 0.050 & 67 & 2.673 & 0.057 & 88 & 2.908 & 0.063 & 70 & 2.651 & 0.043 & 297 & 2.598 & 0.056 \\
\hline 0.8 & 25 & 1.818 & 0.069 & 22 & 1.644 & 0.047 & 34 & 2.890 & 0.052 & 44 & 3.045 & 0.068 & 53 & 2.825 & 0.054 & 178 & 2.604 & 0.059 \\
\hline 0.9 & 5 & 2.623 & 0.053 & 5 & 1.798 & 0.055 & 5 & 2.743 & 0.046 & 6 & 2.446 & 0.069 & 4 & 2.099 & 0.037 & 25 & 2.356 & 0.054 \\
\hline Total & 287 & 2.155 & 0.072 & 311 & 1.683 & 0.049 & 517 & 2.646 & 0.053 & 719 & 2.967 & 0.058 & 826 & 2.766 & 0.043 & 2,660 & 2.604 & 0.053 \\
\hline
\end{tabular}


Table VI

\section{D efinition and Signs of $V$ ariables}

\begin{tabular}{|c|c|c|c|}
\hline Variables & Definitions & $\begin{array}{l}\text { Predicated } \\
\text { Signs }\end{array}$ & $\begin{array}{l}\text { Empirical } \\
\text { Findings }\end{array}$ \\
\hline$Q$ & $\begin{array}{l}\text { A proxy of Tobin's Q as the adjusted market value of the firm. It is calculated as } \\
\text { the market value of equity and book value of debt over book value of asset. }\end{array}$ & & \\
\hline ROA & $\begin{array}{l}\text { A proxy of corporate accounting profitability. It is calculated as the net profit } \\
\text { over total assets. }\end{array}$ & & \\
\hline Private & $\begin{array}{l}\text { A dummy variable of ownership. If the government is a shareholder of an } \\
\text { enterprise, it is } 0 \text {; otherwise, as } 1 .\end{array}$ & + & + \\
\hline Prilarge & $\begin{array}{l}\text { A dummy variable of ownership. If the government is the largest shareholder of } \\
\text { an enterprise, it is } 0 \text {; otherwise, as } 1 .\end{array}$ & + & + \\
\hline State & $\begin{array}{l}\text { The cash flow rights of the government as well as approximately the voting rights } \\
\text { of the government. It is calculated as the state-owned shares over total common } \\
\text { shares. }\end{array}$ & - & $U$ \\
\hline Herfindhal & $\begin{array}{l}\text { An indicator of ownership concentration. Calculated as } \sum\left(\mathrm{Si}^{\wedge} 2\right) / 10 \text { where } \mathrm{Si} \text { is } \\
\text { the large shareholders' holding fraction, } \mathrm{i} \text { is from } 1 \text { to } 10 \text {. }\end{array}$ & + & + \\
\hline $\begin{array}{l}\text { Large } \\
\text { Private }\end{array}$ & $\begin{array}{l}\text { A dummy variable of ownership. If there exists a non-government major } \\
\text { shareholder, it is } 1 \text {; otherwise, } 0 \text {. }\end{array}$ & + & + \\
\hline Second & $\begin{array}{l}\text { A dummy variable of ownership. If the second largest shareholder has more than } \\
10 \% \text { voting rights, it is } 1 \text {; otherwise, } 0 \text {. }\end{array}$ & + & 0 \\
\hline Manager & $\begin{array}{l}\text { Managerial shareholding. It is calculated as the total shares held by senior } \\
\text { managers over the total common shares. }\end{array}$ & + & $\begin{array}{l}\text { O for } \mathrm{Q} ; \\
+ \text { for } \mathrm{ROA}\end{array}$ \\
\hline Size & $\begin{array}{l}\text { Corporate size. It is calculated as the log form of total assets as for } \mathrm{Q} \text { and } \\
\text { Market-to-Book value; log form of sales as for ROA and other accounting profit } \\
\text { measures. }\end{array}$ & + & $\begin{array}{l}\text { - for } \mathrm{Q} ; \\
+ \text { for } \mathrm{ROA}\end{array}$ \\
\hline Tangible & $\begin{array}{l}\text { An indicator of the asset structure or the capital intensity. It is calculated as the } \\
\text { fixed assets over total assets. }\end{array}$ & - & - \\
\hline Gear & $\begin{array}{l}\text { An indicator of the capital structure. It is calculated as the total liability over the } \\
\text { book value of total assets. }\end{array}$ & + & - \\
\hline Age & $\begin{array}{l}\text { Firm age. It is calculated as the existence years of the firm since they were } \\
\text { founded. }\end{array}$ & - & - \\
\hline Exchange & $\begin{array}{l}\text { Stock exchange. It is } 1 \text { if the firms listed on Shanghai Stock Exchange; } 0 \text { if listed } \\
\text { on Shenzhen Stock Exchange. }\end{array}$ & $?$ & $\begin{array}{l}0 \text { for } R O A: \\
\quad+\text { for } Q\end{array}$ \\
\hline Industry & $\begin{array}{l}\text { The industries that a firm mainly operates. } 20 \text { dummy variables as the firms } \\
\text { distributed in } 21 \text { industries. It includes agriculture, chemical industry, } \\
\text { conglomerate, construction, electricity equipment, information technology, } \\
\text { electronics, finance, food \& wine, machinery, metal, motor, papers, petrochem, } \\
\text { pharmacy, real estate, shopping and travel, textile, transport, utility and others. } \\
\text { The data of industrial classification is from China Security Daily. }\end{array}$ & & \\
\hline Year & $\begin{array}{l}\text { Time effect. } 4 \text { dummy variables as the data in different years. It covers year } \\
1994,1995,1996,1997 \text { and } 1998 \text {. }\end{array}$ & & \\
\hline
\end{tabular}




\section{William Davidson Institute Working Paper 395}

Table VII

\section{Compare the $V$ alue and Characteristics of Firms}

This table presents other firm characteristics and compares them. NSEs are the enterprises with no state shareholding, which are also called private enterprises. NSL are the firms whose largest shareholder is not the state (Non-State Largest shareholder) and SL are the firms where the State is the Largest shareholder. NSmaj are the enterprises where a major shareholder is the non-government and Smaj are the enterprises where the government holds more than $50 \%$. The comparison of means is based on student t-statistics. It is significantly different, except for the ROE. Under the whole dataset without ruling out outliers, the Mann-Whitney $U$ test is used to compare the medians of the two samples with the null hypothesis that median(ME)=median(NSE), if taking the MEs and NSEs as an example. The statistics is, for example, $U_{n s e}=n_{n s e} n_{m e}+\frac{n_{n s e}\left(n_{n s e e}+1\right)}{2}-S_{n s e}$, $U_{m e}=n_{n s e} n_{m e}+\frac{n_{m e}\left(n_{m e}+1\right)}{2}-S_{m e}$. It indicates whether there are significant difference by asterisks against latter column of the compared variables; $* * *$ as $\mathrm{p}$ or $\mathrm{z}$-value $\leq 1 \%$, $* * \mathrm{p}$ or $\mathrm{z}$-value $\leq$ $5 \%, *$ p or $\mathrm{z}$-value $\leq 10 \%$.

\begin{tabular}{|c|c|c|c|c|c|c|c|c|}
\hline Items & & NSES & MEs & NSL & SL & NSmaj & Smaj & All \\
\hline \multirow[t]{2}{*}{$\mathrm{Q}$} & Mean & 2.935 & $2.467^{\star \star \star}$ & 2.817 & $2.457^{\star \star \star}$ & 2.995 & $2.547^{\star \star \star}$ & 2.604 \\
\hline & Median & 2.547 & $2.197^{\star \star \star}$ & 2.450 & $2.190^{\star \star \star}$ & 2.603 & $2.303^{\star \star \star}$ & 2.291 \\
\hline \multirow[t]{2}{*}{ ROA } & Mean & 0.059 & $0.050 * \star \star$ & 0.056 & $0.050 * * *$ & 0.074 & $0.054^{\star * *}$ & 0.053 \\
\hline & Median & 0.063 & $0.054^{* \star *}$ & 0.063 & $0.054^{\star \star \star}$ & 0.074 & $0.056^{\star \star \star}$ & 0.058 \\
\hline \multirow[t]{2}{*}{ SECOND } & Mean & 0.276 & $0.385^{\star \star \star}$ & 0.199 & $0.465^{\star \star \star}$ & 0.324 & 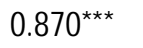 & 0.199 \\
\hline & Median & 0 & $0^{\star \star *}$ & 0 & $0 * \star \star$ & 0 & $1 * \star \star$ & 0.000 \\
\hline \multirow[t]{2}{*}{ MANAGER } & Mean & 0.00006 & $0.00004^{\star \star *}$ & 0.00006 & $0.00004^{\star \star *}$ & 0.0032 & $0.0008 * * *$ & 0.00005 \\
\hline & Median & 0.00002 & $0.00001^{\star * *}$ & 0.00002 & $0.00001^{* \star *}$ & 0.000 & 0.000 *** & 0.00001 \\
\hline \multirow[t]{2}{*}{ SIZE } & Mean & 8.470 & $8.555^{\star \star \star}$ & 8.471 & $8.571^{\star \star \star}$ & 8.563 & $8.676^{\star \star *}$ & 8.530 \\
\hline & Median & 8.412 & 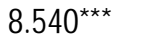 & 8.413 & $8.559 * \star \star$ & 8.509 & 8.645 & 8.501 \\
\hline \multirow[t]{2}{*}{ TANGIBLE } & Mean & 0.248 & 0.246 & 0.247 & 0.246 & 0.248 & 0.251 & 0.246 \\
\hline & Median & 0.215 & 0.222 & 0.216 & 0.223 & 0.219 & 0.225 & 0.219 \\
\hline \multirow[t]{2}{*}{ GEAR } & Mean & 0.398 & $0.441^{\star \star \star}$ & 0.407 & $0.443^{\star \star \star}$ & 0.370 & $0.477^{\star \star \star}$ & 0.429 \\
\hline & Median & 0.393 & $0.440 * * *$ & 0.400 & $0.448^{\star \star \star}$ & 0.373 & $0.459 * \star \star$ & 0.424 \\
\hline \multirow[t]{2}{*}{ AGE } & Mean & 11.764 & $17.497^{\star \star \star}$ & 13.372 & $17.517^{\star \star \star}$ & 12.089 & $15.545^{\star \star}$ & 15.820 \\
\hline & Median & 7 & $8^{\star \star \star}$ & 7 & $8^{* \star *}$ & 7 & 7 & 8 \\
\hline Observations & & 778 & 1882 & 1089 & 1571 & 348 & 1028 & 2660 \\
\hline
\end{tabular}


Table VIII

\section{Corporate $V$ alue in Different Enterprises}

This table reports the regressions of Q and ROA on whether the government is a shareholder and whether the government is the largest shareholder with the 2660 firm-year observations. Private is the dummy variable that is 0 when the government is not a shareholder. The firms with Private as 1 is the so-called private enterprises, since they have no direct government shareholding. Largest is the dummy variable that is 0 when the government is the largest shareholder. The firms with Largest as 0 are the firms controlled by the government. Both the robust pooled OLS regression (OLS) and the maximum likelihood panel model regression (MLP) are performed. OLS regressions report the Rsquared and F-statistics in the table. MLP reports the log likelihood ratios and LR chi-squared in the table. Significance is the probability for the respective statistics to be significant. Standard deviations are in the parenthesis. The asterisks behind the coefficient show the range of P-values: *** as p-value $\leq$ $1 \%, * *$ p-value $\leq 5 \%, *$ p-value $\leq 10 \%$.

In the analysis of categorized enterprises, the discriminant analyses and the logit analyses with the artificial setting taking the types of the enterprises as success rates are performed. It was achieved similar results to these of the comparison statistics and dummy-variable regressions. These tables are therefore not reported.

\begin{tabular}{|c|c|c|c|c|c|c|c|c|}
\hline & \multicolumn{4}{|c|}{$Q$} & \multicolumn{4}{|c|}{$\mathrm{ROA}$} \\
\hline & OLS & MLP & OLS & MLP & OLS & MLP & OLS & MLP \\
\hline \multirow[t]{2}{*}{ Private } & $0.242^{\star *}$ & $0.229^{\star \star \star *}$ & & & $0.006^{\star \star}$ & $0.005^{\star \star}$ & & \\
\hline & $(0.077)$ & $(0.065)$ & & & (0.003) & $(0.003)$ & & \\
\hline \multirow[t]{2}{*}{ Prilarge } & & & $0.172^{\star \star \star}$ & $0.161^{\star \star *}$ & & & $0.005^{\star \star}$ & $0.005^{\star \star}$ \\
\hline & & & $(0.061)$ & $(0.060)$ & & & $(0.003)$ & $(0.002)$ \\
\hline \multirow[t]{2}{*}{ Second } & $0.114^{*}$ & $0.115^{\star}$ & 0.087 & 0.080 & -0.005 & -0.003 & -0.005 & -0.004 \\
\hline & (0.063) & $(0.066)$ & $(0.067)$ & $(0.068)$ & $(0.003)$ & $(0.003)$ & $(0.003)$ & $(0.003)$ \\
\hline \multirow[t]{2}{*}{ Manager } & 0.159 & 0.603 & 0.413 & 0.825 & $0.305^{\star \star \star}$ & $0.284^{\star \star}$ & 0.310 *** & $0.288^{\star *}$ \\
\hline & (1.883) & (2.849) & (1.868) & (2.852) & $(0.069)$ & (0.144) & $(0.070)$ & (0.113) \\
\hline \multirow[t]{2}{*}{ Herfindhal } & $6.452^{\star \star \star}$ & $9.362^{\star \star *}$ & $6.513^{\star \star \star}$ & $9.426^{\star \star \star}$ & $0.184^{\star \star \star}$ & $0.295^{\star \star \star}$ & $0.186^{\star \star \star}$ & $0.298^{\star \star \star}$ \\
\hline & (1.646) & (2.034) & (2.067) & (2.033) & $(0.066)$ & $(0.090)$ & $(0.066)$ & $(0.091)$ \\
\hline \multirow[t]{2}{*}{ Size } & $-0.583^{\star \star}$ & $-0.608^{\star \star \star}$ & $-0.581^{\star \star \star}$ & $-0.608^{\star \star \star}$ & $0.029 \star \star \star$ & $0.034^{\star \star \star}$ & $0.030^{\star * \star}$ & $0.034^{\star * *}$ \\
\hline & $(0.062)$ & $(0.070)$ & $(0.062)$ & $(0.070)$ & $(0.004)$ & $(0.003)$ & $(0.004)$ & $(0.003)$ \\
\hline \multirow[t]{2}{*}{ Tangible } & -0.496 & -0.433 & -0.493 & -0.429 & -0.025 & -0.028 & $-0.025^{\star \star}$ & -0.028 \\
\hline & $(0.227)$ & $(0.213)$ & $(0.226)$ & $(0.213)$ & $(0.008)$ & $(0.008)$ & $(0.008)$ & $(0.008)$ \\
\hline \multirow[t]{2}{*}{ Gear } & $-1.702^{\star \star \star}$ & $-1.424^{\star \star \star}$ & $-1.721^{\star \star \star}$ & $-1.434^{\star \star *}$ & $-0.164^{\star \star \star}$ & $-0.154^{\star \star \star}$ & $-0.164^{\star \star \star}$ & $-0.154^{\star \star \star}$ \\
\hline & $(0.355)$ & $(0.175)$ & $(0.360)$ & $(0.175)$ & $(0.025)$ & $(0.007)$ & $(0.025)$ & $(0.007)$ \\
\hline \multirow[t]{2}{*}{ Age } & $-0.004^{\star \star *}$ & -0.005 & $-0.005^{\star \star *}$ & -0.005 & $-0.0002^{\star \star \star}$ & $-0.0003^{*}$ & $-0.0002^{\star \star \star}$ & $-0.0003^{\star *}$ \\
\hline & $(0.001)$ & (0.002) & $(0.001)$ & $(0.002)$ & $(0.000)$ & $(0.000)$ & $(0.000)$ & $(0.000)$ \\
\hline \multirow[t]{2}{*}{ Exchange } & $-0.178^{* *}$ & -0.118 & $-0.177^{\star \star}$ & -0.120 & -0.003 & -0.001 & -0.003 & -0.001 \\
\hline & $(0.052)$ & (0.069) & $(0.053)$ & $(0.070)$ & $(0.002)$ & $(0.003)$ & $(0.002)$ & $(0.003)$ \\
\hline Industry & Yes. & Yes. & Yes. & Yes. & Yes. & Yes. & Yes. & Yes. \\
\hline Year & Yes. & Yes. & Yes. & Yes. & Yes. & Yes. & Yes. & Yes. \\
\hline \multirow[t]{2}{*}{ Constant } & $8.130^{\star \star *}$ & 8.351 *** & $8.109^{\star \star \star}$ & $8.353^{\star * *}$ & $-0.110^{\star \star \star}$ & $-0.136^{\star \star \star}$ & $-0.111^{\star \star \star}$ & $-0.137^{* \star *}$ \\
\hline & $(0.545)$ & $(0.627)$ & $(0.551)$ & $(0.629)$ & $(0.029)$ & $(0.025)$ & $(0.029)$ & $(0.025)$ \\
\hline ------------ & ----------- & ------------ & ----------- & ------------- & ----------- & ------------ & ------------ & ------------ \\
\hline R-squared & 0.504 & & 0.511 & & 0.427 & & 0.425 & \\
\hline Log Likelihood & & -4357.9 & & -4360.6 & & 4154.7 & & 4154.5 \\
\hline F statistic & 34.95 & & 34.83 & & 14.10 & & 14.08 & \\
\hline Chi2 statistics & & 410.29 & & 402.94 & & 772.32 & & 771.82 \\
\hline Significance & 0.000 & 0.000 & 0.000 & 0.000 & 0.000 & 0.000 & 0.000 & 0.000 \\
\hline
\end{tabular}


Table IX

\section{Corporate $V$ alue and State Shareholding}

This table reports the regressions of $Q$ and ROA on the fraction of government shareholding with the 2660 firm-year observations. State2 is the squared form of state shareholding (State). Both the robust pooled OLS regression (OLS) and the maximum likelihood random effect panel model regression (MLP) are performed. OLS regressions report the R-squared and F-statistics in the table. MLP reports the log likelihood ratios and LR chi-squared in the table. Significance is the probability for the respected statistics to be significant. Standard deviation are in the parenthesis. The asterisks behind the coefficient show the range of P-values: $* * *$ as p-value $\leq 1 \%, * *$ p-value $\leq 5 \%, *$ p-value $\leq 10 \%$.

\begin{tabular}{|c|c|c|c|c|c|c|c|c|}
\hline & \multicolumn{4}{|c|}{ Q } & \multicolumn{4}{|c|}{ ROA } \\
\hline & (1) & (2) & (3) & (4) & (1) & (2) & (3) & (4) \\
\hline & OLS & MLP & OLS & MLP & OLS & MLP & OLS & MLP \\
\hline \multirow[t]{2}{*}{ State } & $-2.294^{\star \star \star}$ & 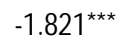 & $-1.493^{\star \star *}$ & $-1.367^{\star \star \star}$ & $-0.067^{\star \star \star}$ & $-0.048^{\star \star \star}$ & $-0.035^{\star \star}$ & $-0.039 * *$ \\
\hline & $(0.349)$ & $(0.414)$ & $(0.335)$ & $(0.412)$ & $(0.016)$ & $(0.018)$ & $(0.016)$ & $(0.017)$ \\
\hline \multirow[t]{2}{*}{ State2 } & $2.813^{\star \star \star}$ & $2.213^{\star \star \star}$ & $2.562^{\star \star \star}$ & $2.318^{\star \star \star}$ & $0.087^{\star \star \star}$ & $0.059^{\star \star}$ & $0.045^{\star \star}$ & $0.048^{\star \star}$ \\
\hline & $(0.444)$ & $(0.612)$ & $(0.412)$ & $(0.580)$ & $(0.022)$ & $(0.026)$ & $(0.021)$ & (0.024) \\
\hline \multirow[t]{2}{*}{ Second } & & & $0.205^{\star \star \star}$ & $0.188^{\star \star *}$ & & & -0.005 & -0.003 \\
\hline & & & $(0.078)$ & $(0.067)$ & & & (0.003) & $(0.003)$ \\
\hline \multirow[t]{2}{*}{ Manager } & & & 1.211 & 1.475 & & & $0.314^{\star * *}$ & $0.298^{\star *}$ \\
\hline & & & (1.793) & $(2.826)$ & & & $(0.080)$ & $(0.125)$ \\
\hline \multirow[t]{2}{*}{ Large Private } & & & $0.416^{\star *}$ & $0.426^{\star \star *}$ & & & $0.013^{\star \star \star}$ & $0.013^{\star \star \star}$ \\
\hline & & & $(0.189)$ & $(0.107)$ & & & $(0.005)$ & $(0.005)$ \\
\hline \multirow[t]{2}{*}{ Size } & & & $-0.642^{\star \star \star}$ & $-0.654^{\star \star \star}$ & & & $0.012^{\star \star \star}$ & $0.014^{\star \star \star}$ \\
\hline & & & $(0.065)$ & $(0.070)$ & & & $(0.002)$ & $(0.001)$ \\
\hline \multirow[t]{2}{*}{ Tangible } & & & $-0.524^{\star *}$ & $-0.474^{\star \star}$ & & & $-0.029 * \star \star$ & $-0.033^{\star \star \star}$ \\
\hline & & & $(0.224)$ & $(0.211)$ & & & $(0.009)$ & $(0.009)$ \\
\hline \multirow[t]{2}{*}{ Gear } & & & $-1.661^{\star \star \star}$ & $-1.389 * \star *$ & & & $-0.168^{\star \star \star \star}$ & -0.160 *** \\
\hline & & & $(0.359)$ & $(0.174)$ & & & $(0.027)$ & $(0.007)$ \\
\hline \multirow[t]{2}{*}{ Age } & & & $-0.004^{\star \star \star}$ & $-0.005^{\star \star}$ & & & $-0.0002^{\star \star \star}$ & $-0.0003^{\star \star *}$ \\
\hline & & & $(0.001)$ & $(0.002)$ & & & $(0.0001)$ & $(0.0001)$ \\
\hline \multirow[t]{2}{*}{ Exchange } & & & $0.158^{\star \star \star}$ & -0.102 & & & -0.002 & -0.001 \\
\hline & & & $(0.051)$ & $(0.069)$ & & & $(0.002)$ & $(0.003)$ \\
\hline Industry & Yes. & Yes. & Yes. & Yes. & Yes. & Yes. & Yes. & Yes. \\
\hline Year & Yes. & Yes. & Yes. & Yes. & Yes. & Yes. & Yes. & Yes. \\
\hline \multirow[t]{2}{*}{ Constant } & $2.686^{\star \star \star}$ & $2.918^{\star \star \star}$ & $8.580^{\star \star \star}$ & $8.674^{\star \star \star}$ & $0.080^{\star \star \star}$ & $0.038^{\star \star \star}$ & $-0.096^{\star \star \star}$ & $-0.120^{\star \star *}$ \\
\hline & $(0.218)$ & $(0.233)$ & $(0.572)$ & $(0.621)$ & $(0.011)$ & $(0.010)$ & $(0.032)$ & $(0.027)$ \\
\hline R-squared & 0.123 & & 0.228 & & 0.067 & & 0.293 & \\
\hline Log Likelihood & & -4449.3 & & -4343.9 & & 3879.2 & & 3594.9 \\
\hline F statistic & 27.08 & & 34.63 & & 8.24 & & 12.68 & \\
\hline Chi2 statistics & & 237.85 & & 438.14 & & 250.40 & & 727.60 \\
\hline Significance & 0.000 & 0.000 & 0.000 & 0.000 & 0.000 & 0.000 & 0.000 & 0.000 \\
\hline Turning point & 0.408 & 0.411 & 0.291 & 0.295 & 0.385 & 0.407 & 0.389 & 0.378 \\
\hline
\end{tabular}


Table X

\section{W elfare Expenditure, Board M ember Turnover, Subsidies and the Size of the State Shareholding Stakes}

This table regresses the expenditure for employee welfare, board members turnovers and income from government's subsidies on state shareholding, respectively. To prevent from the missing controlling variables, it reports the results of panel-model estimation, based on the maximum log likelihood random effect estimation. Significance is the probability that the respective statistics will be significant. Standard deviations are in the parenthesis. The asterisks behind the coefficient show the range of Pvalues: $* * *$ as p-value $\leq 1 \%, * *$ p-value $\leq 5 \%, *$ p-value $\leq 10 \%$.

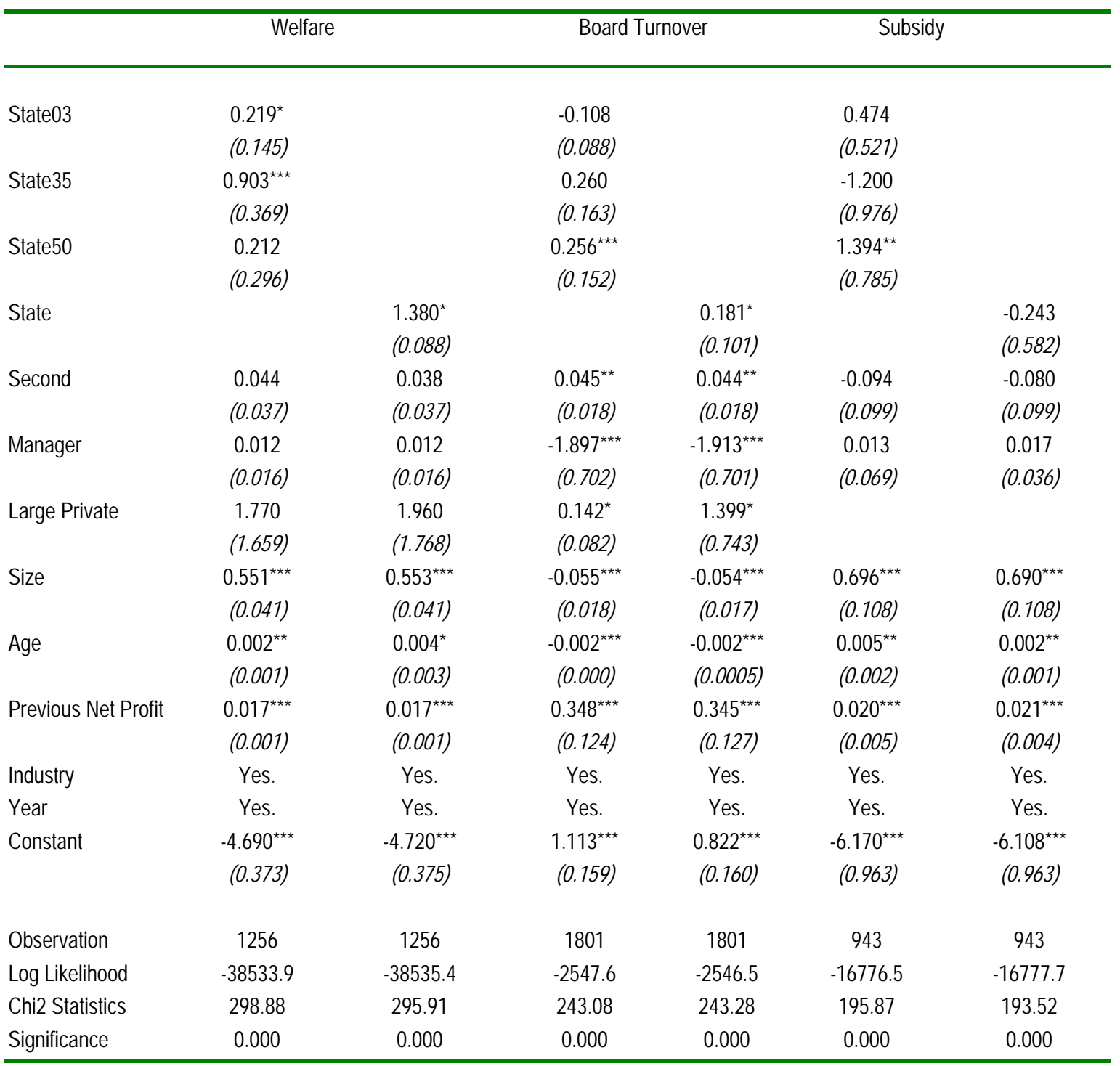


Appendix 1:

\section{$D$ ata Sources}

\begin{tabular}{|c|c|c|}
\hline & Data Sources & Reliability \\
\hline Share price data & Datastream Inc. & $\begin{array}{l}\text { Established International Renown Data } \\
\text { Specialist }\end{array}$ \\
\hline $\begin{array}{l}\text { Accountancy data } \\
\text { before IPO }\end{array}$ & Taiwan Economic Journal & $\begin{array}{l}\text { The leading data specialist company in } \\
\text { Taiwan and the major Chinese data } \\
\text { vendor to Reuters, Datastream etc. }\end{array}$ \\
\hline $\begin{array}{l}\text { Accountancy data after } \\
\text { IPO }\end{array}$ & Genius Inc. & $\begin{array}{l}\text { More than } 80 \% \text { Chinese investment } \\
\text { bankers and security analysts rely on } \\
\text { the data provided by this company. }\end{array}$ \\
\hline State ownership & Genius Inc. & \\
\hline Board of directors & Taiwan Economic Journal & \\
\hline Large shareholders & Beijing Hairong Inc. & $\begin{array}{l}\text { The major financial data specialist } \\
\text { company in Beijing. }\end{array}$ \\
\hline Industrial classification & China Securities Daily & $\begin{array}{l}\text { The leading newspaper on finance and } \\
\text { securities in China }\end{array}$ \\
\hline Block transfer & China Securities Daily & \\
\hline State-share transfer & Securities Times & $\begin{array}{l}\text { A major newspaper on securities in } \\
\text { China }\end{array}$ \\
\hline \multicolumn{3}{|c|}{$\begin{array}{l}\text { With regards to accountancy and ownership data, the validity of the data sets is crosschecked and } \\
\text { missing points were made up, based on annual reports form the website managed by the Shenzhen } \\
\text { Stock Exchange. http://www.cninfo.com.cn/. }\end{array}$} \\
\hline
\end{tabular}


Appendix 2:

\section{Shanghai State A sset M anagement System}

This chart describes the organisational form of the Shanghai State Asset Management System. The arrows represent the control, which can be implemented by nominating or appointing the crucial official in this pyramid. The state asset management system also covers state shareholdings. As a general rule, the agencies with direct control responsible for specific public listed companies can be numerous, but this organisational chart shows the control of the government and ultimately the communist party to these numerous agencies is tight.

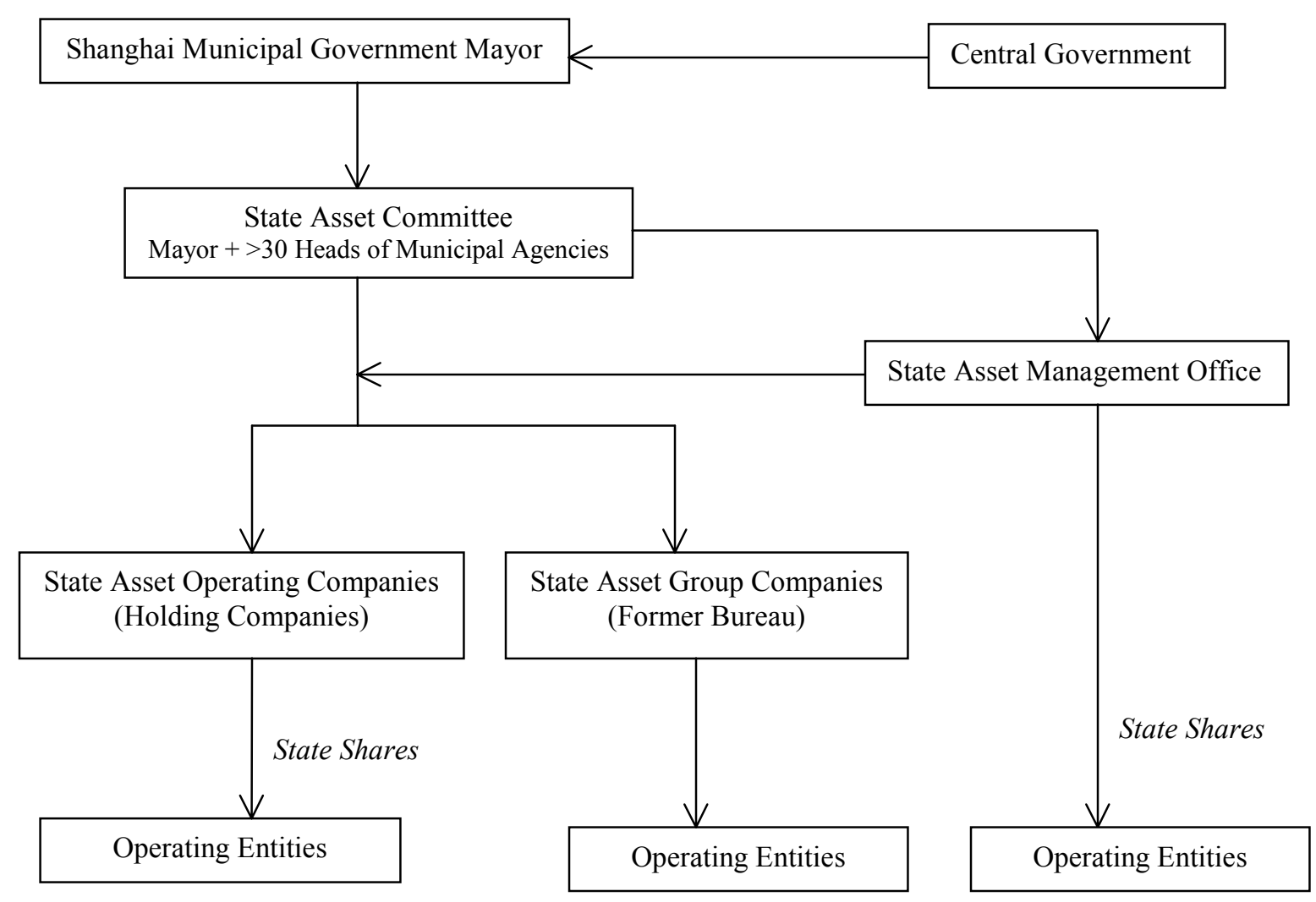


Appendix 3:

\section{Reports of Regression Results of Control V ariables}

Besides documenting the impact of state shareholding, tables 8 and 9 also show the impacts of other corporate characteristics on corporate value in China.

\section{A. Ownership}

This analysis provides supports to the arguments of Gomes and Novaes (1999) that multiple large shareholders improve corporate value, but it creates costs as well. The signs of Second are significantly positive when it is regressed with Q, but not significant when regressing with ROA. Minority shareholders benefit from the presence of multiple large shareholders, as it reduces the private benefits of control and facilities takeovers. The market values of the multiple large shareholders are therefore high. However, in corporate operations, the multiple shareholders prevent from efficient decisions due to bargaining problems. It offsets the value-added by monitoring the tunneling behavior of the largest shareholder. Therefore, the presence of the multiple large shareholders does not significantly influence accounting profits.

It is also interesting to find that managerial ownership has no relation to $\mathrm{Q}$, but a positive impact on ROA. During the IPO period, the shares sold to employees and managers are priced at a significant discount. The initial managerial holding depends on the rationing of the discounted shares and the personal budget constraints of these managers. Furthermore, the law forbids the managers to trade their shares when they are in office. Thus the sizes of managerial shareholding stakes do not signal to the market for the quality of the firms. However, given that the shares compose a significant part of the personal wealth of the managers, the managers may have more incentive to maximize corporate profitability when their personal wealth is more affiliated with corporate profits. This bonding could explain why managerial holding is positively correlated to ROA. It is consistent with Jensen and Meckling (1976). The spline forms of managerial holding were also tested. However, there is not a nonmonotonic relation between managerial ownership and corporate value, which differs from the findings in United States. The reason for this is possibly that the Chinese managers' holdings are only $0.005 \%$ due to their personal budgets, well below the first threshold of 5\% identified by Morck et al (1988). 
The significant positive signs for the coefficient of the LargePrivate in Table XIII suggest that the presence of a majority non-government shareholder improves corporate value. This is consistent with the convergence-of-interest hypothesis of the large shareholder theory. The significant positive Herfindhal index on corporate value in Table XII also supports that concentration of shareholdings improves corporate value. It is consistent with Shleifer and Vishny (1997).

B. Size

The signs for the coefficients of the size on $\mathrm{Q}$ are significantly negative. It was also found that it is negative with market-to-book value. This implies that the large enterprises tend to have a relatively low corporate value. This result is confirmed by Xu and Wang (1999) and Qi et al (2000). However, when regressing ROA on Size, it is found that the size impact is significantly positive. It remains significantly positive, if we use the $\log$ form of total asset. This is consistent with Hall and Weiss (1967). This contradicting result may be due to the transitional feature of China's stock market and its enterprises. The positive sign of size on ROA shows that larger-sized firms are more profitable, which is consistent with the theory of scales of economies. However, the larger-sized firms are perhaps more difficult to be restructured than the smaller-sized firms. The net present values of the larger-sized firms are therefore lower.

C. Tangibility

The asset structure influences corporate value. The firms with large intangible assets are valued higher.

D. Leverage

This study does not support the theory of static tradeoff between tax shield and costs of financial distress under relatively soft budget constraints. It finds that higher debts are associated with a lower corporate value in China. This is actually true in most countries, where the debts to asset ratios are negatively correlated with marketto-book value and ROA (Rajan and Zingales 1995 and Booth et al 2000). The pecking order theory may interpret this stylized fact. That is, only when the firms have no internal financing resources will they resort to borrowing. Capital structure is the active choice of the firms. This implies that the firms with high earnings have low gearing ratios. This causality issue complicates the models' specification. However, the results of the U-shaped pattern are robust-actually, more significant-when the gearing ratios are removed from the regressions. 


\section{E. Age}

Firms' age has a negative impact on corporate value, which is consistent with the predication. The theory of path dependence suggests that old firms have more entrenched problems. This is reflected in lower profitability and market value. In addition, firms' age is highly correlated to listing time. It also finds that the more recently listed companies normally have higher profitability.

F. Stock exchange

The signs of stock exchange dummy are marginally significantly negative for the market-based Q in the OLS regressions, but not significant for ROA. It implies that, during 1994-1998, the investors favor Shenzhen Stock Exchange a bit more than Shanghai. Comparing the stock index between 1994 and 1998 (see Table I), it is confirmed by the fact that the Shenzhen composite index rose $144.6 \%$, but Shanghai only $77.0 \%$. 


\section{William Davidson Institute Working Paper 395}

\section{Endnotes}

\footnotetext{
${ }^{1}$ Mixed enterprises are the firms with the ownership mixed government ownership with private
} ownership. That is, the PLCs with partial government shareholding in my sample. The firms without any government shareholding may be loosely termed as private enterprises.

${ }^{2}$ For instance, analyzing the enterprises fully owned by the state (SOEs), Vickers and Yarrow (1988) summarize theoretical literature and argue that state ownership is inefficient. Surveying more than 61 papers, Meggingson and Netter (2000) conclude that "[the weight of empirical research] is now decisively in favor of the proposition that privately-owned firms are more efficient and more profitable than otherwise-comparable state-owned firms".

${ }^{3}$ Morck et al. (1988) document the non-monotonic relationship between management ownership and market value of the firm; McConnell and Servaes (1990) document the concave relationship between insider ownership and Tobin's Q. These studies actually take the ownership variables as being crosssectionally continuous and find the relationship between corporate value and the size of the shareholding stakes of a certain type of owners in a large sample of firms.

${ }^{4}$ There is no fundamental difference between two stock exchanges in legislation and regulations. Separating the stock market into two stock exchanges aims at encouraging competition between them. ${ }^{5}$ In 1994, the Company Law (1993) that formally legislates and governs the joint stock companies with the Anglo-American featured corporate governance structures took effect. In the same year, the China Securities Regulatory Commission introduced a series of six rules called as Contents and Forms of The Information Release by PLCs, which formatted the annual reports. In 1999, a new version of company Law based on the 1993 Company Law was stipulated.

${ }^{6}$ Furthermore, due to regulations, the fund management companies are excluded the government shareholder.

${ }^{7}$ Otherwise, I would have had to use the share prices from the market of foreign investors, but the market values may not be comparable, like the home bias problem.

${ }^{8}$ The largest industrial quoted company, Shanghai Petrochemical Company Limited, has total assets of \$2.7 billion, fixed asset \$1.4 billion and income \$1.26 billion. The total assets of the smallest Chinese PLC Xiamen Xiongzhen are only $\$ 14.3$ million and income $\$ 4.4$ million. 
${ }^{9}$ The Chinese PLCs have a so-called supervisory board. The Chinese supervisory board is in charge of supervising whether there are illegal behaviors of the managers and directors. It has no rights to interfere with corporate management and strategy. This is fundamentally different from the supervisory board in Germany. These Chinese PLCs are actually featured with Anglo-American typed governance structures.

${ }^{10}$ LLS (1999) admit that the high proportion of state shareholding in their findings is due to the selection of their sample only with the large sized companies. Faccio and Lang (2000)'s study is based on most of firms listed on the stock exchanges of some western European countries. Therefore, the results of this study is compared with Faccio and Lang (2000).

${ }^{11}$ Aggregating the shares of these atomisic individual shareholders is not much meaningful, as they usually do not collaboratively exert their voting powers.

12 The weakest link concept (LLS 1999) is adopted here. If company A holds $15 \%$ of company B and company B holds $20 \%$ of company $\mathrm{C}$, it takes that company A holds $15 \%$ of company $\mathrm{C}$.

${ }^{13}$ It reduces the difficulty to examine the impact of the government shareholder in the following sections.

${ }^{14}$ This is distinctly contrast to other countries (Claessens et al 2000 and Faccio and Lang 2000). LLS (1999) admit that the high government shareholding in their report is due to the bias of sample selection only with very large firms.

${ }^{15}$ The LLS method does not trace the owners of unlisted firms. My dataset does not allow me to improve the LLS method. That is, some of the domestic unlisted companies are disguised family owners. This bias is admitted, but it does not bias my study on the impact of government sharheolding on corporate value.

${ }^{16}$ A significant proportion of PLCs is under the control of another domestic company. With the same problem as that other researchers encountered, I could not trace down the ultimate shareholder of a company unlisted on the stock market. Thus, there is admittedly a bias to reveal the ultimate shareholding structures under the methodology of LLS (1999); however, this bias only strengthens the argument of this paper that the government shareholder in the China's PLCs is highly influential.

${ }^{17}$ It may be unnecessary to consider the pyramids or cross-shareholdings, because the intermediate joint-stock company stands in the way of the influence of government officials. A joint-stock company is not the government's agent and it has its corporate interest and business-oriented behaviors. 
Government indirect shareholding has different impacts from its direct holding. More importantly, technically, the traceable pyramids and cross-shareholding of the government shareholder is marginal and around $1 \%$ changes of state shares does not change my empirical results.

${ }^{18}$ It is the largest share stake of the government in the PLCs.

${ }^{19}$ For instance, the study of Chung and Pruitt (1994) shows the explanatory power of simplified Q is at least $96.6 \%$ of the Lindenberg and Ross (1981)'s Tobin's Q.

${ }^{20}$ LLS (1999) showed that relatively few of these firms around the world are widely held and the Berle and Means' image of dispersed shareholding structure is not correct for these sampled countries, except for the United States. However, most shareholders still need delegate their control to the managers and the separation of management rights and cash flow rights still exists. The fundamental problem of principal-agent can not be totally solved by a concentrated shareholding structure.

${ }^{21}$ This argument is based on the intuition that the harmful effects of state intervention have a greater impact under state ownership than under state regulation (Megginson and Netter 2000). It is supported by the fact that the partial ownership of state provides the access to insider information.

${ }^{22}$ Moulton (1986) shows that the standard errors of the OLS estimation for the one-way error component model with the unbalanced panel dataset are biased. The GEE population-averaged panel data models are used to check the robustness of the MLP models. The results are very similar and the tables of the GEE models are not presented here.

${ }^{23}$ McConnell and Servaes (1990) employ the quadratic technique to show a hump-shaped relationship between insider ownership and Tobin's Q. Morck et al (1988) use the piecewise regressions show the non-monotonic relationship between managerial ownership and corporate value.

${ }^{24}$ In addition, the tangibility ratio also helps to standardize for accounting artifacts (Demsetz and Lehn 1985).

${ }^{25}$ Conventionally, tangibility is normally captured by using the R\&D expense or advertising expense data, but this information is not required to be disclosed under the Chinese accountancy standards for PLCs.

${ }^{26}$ No-State-shares Enterprises. The abbreviation of NSEs is used, because the term of private enterprises may confuse the enterprises without a government shareholder with the enterprises privately owned by an individual. 
${ }^{27}$ More importantly, it is the research approach of the mixed-enterprise literature (e.g. Boardman and Vining 1989).

${ }^{28}$ Although the law allows proxies of voting rights, proxy rights are seldom used in China. The first proxy war happened in 2000 when Tong Baihui collected proxies in order to control Shenli Gufen.

${ }^{29}$ In addition, the highly significant Herfindhal index suggests that ownership concentration creates value in Chinese firms.

30 The finding of Vining and Boardman (1990) includes the enterprises partly owned a fund as the mixed enterprises.

${ }^{31}$ Chen, Firth and Rui (2000) find that there isn't a significant improvement in value after share privatization, which may be used to support the argument that state ownership is irrelevant to corporate performance. In contrast, finding the overall detrimental impact of state ownership, this study shows that China is not an exception.

${ }^{32}$ Starting from 2000, the government is in the discussion to redirect their target on selling the shares, under the financial need to build the social security system.

33 "Measures on the Shareholding Experiment", issued by the State Council, 15 May 1992.

${ }^{34}$ There are about one-third state-share transfer as the free grants in 1998 (China Security Daily 2000).

${ }^{35}$ The actual controlling threshold varies on the specific shareholding structure of a company.

${ }^{36}$ In addition, Eckel and Vermaelen (1986) propose an advantage of the government shareholder as the internalized regulations. They argue that the government does not impose rigid regulations on the firm, if it can influence corporate strategy as a shareholder. This proposal is less intuitive or convincing as for the Chinese case. Moreover, due to political interference and the on-going ownership restructuring, Warren Buffett's committed high quality shareholder argument (1998) may not apply to the Chinese government.

37 The simplified descriptive model here does not differentiate voting rights and cash flow rights, because the separation of voting rights and cash flow rights in China is marginal. With regard to the analytical model, please refer to Tian (2000).

${ }^{38}$ It also implies that the state-solely owned enterprises (SOEs) are theoretically better off than the mixed enterprises, other things being equal. However, in reality, the SOEs are not monitored by the stock market and most of the Chinese SOEs have not built up the modern corporate governance mechanisms yet. 
William Davidson Institute Working Paper 395

${ }^{39}$ The polynomial regressions have no significant signs for the independent variables. $50 \%$ is the point for absolute control. $30 \%$ is also chosen in the piecewise regressions, because CSRC defines the shareholder with more than $30 \%$ as stay in the relative control. Technically, setting the range between $30 \%$ to $50 \%$ in my statistical investigations helps increase the significance.

40 This claim is based on the definition of mixed enterprises as where the government is a shareholder but not the sole owner. 


\section{DAVIDSON INSTITUTE WORKING PAPER SERIES - Most Recent Papers}

The entire Working Paper Series is available at: www.wdi.bus.umich.edu

CURRENT AS OF 10/25/01

\begin{tabular}{|c|c|c|}
\hline Publication & Authors & Date \\
\hline $\begin{array}{l}\text { No. 395: Government Shareholding and the Value of China's Modern } \\
\text { Firms }\end{array}$ & Lihui Tian & Apr. 2001 \\
\hline No. 394: Labor Hoarding in Russia: Where Does it Come from? & $\begin{array}{l}\text { Rouslan Koumakhov amd Boris } \\
\text { Najman }\end{array}$ & June 2000 \\
\hline $\begin{array}{l}\text { No. 393: Ownership Structure, Corporate Governance, And Firm Value: } \\
\text { Evidence from the East Asian Financial Crisis }\end{array}$ & Michael Lemmons and Karl Lins & Apr. 2001 \\
\hline No. 392: Marshall and Labour Demand in Russia: Going Back to Basics & $\begin{array}{l}\text { Jozef Konings and Hartmut } \\
\text { Lehmann }\end{array}$ & Aug. 2001 \\
\hline No. 391: Economic Transition and Elections in Poland & $\begin{array}{l}\text { John E. Jackson, Jacek Klich, and } \\
\text { Krystyna Poznańska }\end{array}$ & June 2001 \\
\hline $\begin{array}{l}\text { No. 390: Effects of Bank Insolvency and Strategic Uncertainty on } \\
\text { Corporate Restructuring in Transition Economies }\end{array}$ & Christa Hainz & Aug. 2001 \\
\hline No. 389: Mark-Up Pricing In Bulgarian Manufacturing & $\begin{array}{l}\text { Rumen Dobrinsky, Boyko } \\
\text { Nikolov, and Nikolay Markov }\end{array}$ & June 2001 \\
\hline $\begin{array}{l}\text { No. } 388 \text { Globalization and Firms' Financing Choices: } \\
\text { Evidence from Emerging Economies }\end{array}$ & $\begin{array}{l}\text { Sergio Schmukler and Esteban } \\
\text { Vesperoni }\end{array}$ & May 2001 \\
\hline $\begin{array}{l}\text { No. } 387 \text { The Distributional Impacts of Indonesia's Financial Crisis on } \\
\text { Household Welfare: A “Rapid Response" Methodology }\end{array}$ & $\begin{array}{l}\text { Jed Friedman and James } \\
\text { Levinsohn }\end{array}$ & Sept. 2001 \\
\hline $\begin{array}{l}\text { No. } 386 \text { Corporate Financial Policies and Performance Prior to Currency } \\
\text { Crises }\end{array}$ & $\begin{array}{l}\text { Arturo Bris, Yrjö Koskinen, and } \\
\text { Vicente Pons }\end{array}$ & June 2001 \\
\hline No. 385 Ownership and Productive Efficiency: Evidence from Estonia & Derek C. Jones and Niels Mygind & Aug. 2001 \\
\hline $\begin{array}{l}\text { No. } 384 \text { Forthcoming in: Journal of Economic Perspectives, } \\
\text { "Institutional Determinants of Labor Reallocation in Transition" Vol. } \\
\text { 16, No. 2, Feb. } 2002 \text {. }\end{array}$ & Tito Boeri and Katherine Terrell & June 2001 \\
\hline $\begin{array}{l}\text { No. } 383 \text { Deindustrialisation and Structural Change During the Post- } \\
\text { Communist Transition }\end{array}$ & $\begin{array}{l}\text { Tomasz Mickiewicz and Anna } \\
\text { Zalewska }\end{array}$ & June 2001 \\
\hline No. 382 Markets and Growth & Štěpán Jurajda and Janet Mitchell & July 2001 \\
\hline $\begin{array}{l}\text { No. } 381 \text { Labor Market Discrimination During Post-Communist } \\
\text { Transition: A Monopsony Approach to the Status of Latvia's Russian } \\
\text { Minority }\end{array}$ & Robert S. Chase & Sept. 2000 \\
\hline No. 380 Dollarization of Liabilities in Non-tradable Goods Sector & Frédéric Chabellard & June 2001 \\
\hline $\begin{array}{l}\text { No. } 379 \text { Lessons from the Russian Meltdown: The Economics of Soft } \\
\text { Legal Constraints }\end{array}$ & Enrico Perotti & Mar. 2001 \\
\hline No. 378 Effective Tax Rates in Transition & Vlad Ivanenko & May 2001 \\
\hline $\begin{array}{l}\text { No. } 377 \text { Some Explanations for Changes in the Distribution of } \\
\text { Household Income in Slovakia: } 1988 \text { and } 1996\end{array}$ & $\begin{array}{l}\text { Thesia Garner and Katherine } \\
\text { Terrell }\end{array}$ & May 2001 \\
\hline $\begin{array}{l}\text { No. } 376 \text { Competition and Enterprise Performance in Transition } \\
\text { Economies: Evidence from a Cross-country Survey }\end{array}$ & $\begin{array}{l}\text { Wendy Carlin, Steven Fries, } \\
\text { Mark Schaffer and Paul Seabright }\end{array}$ & May 2001 \\
\hline $\begin{array}{l}\text { No. } 375 \text { Why More is Actually Less: New Interpretations of China's } \\
\text { Labor-Intensive FDI }\end{array}$ & Yasheng Huang & May 2001 \\
\hline No. 374 Economic Fragmentation and FDI in China & Yasheng Huang & May 2001 \\
\hline $\begin{array}{l}\text { No. } 373 \text { Earnings Disparities in the Czech Republic: Evidence of the } \\
\text { Past Decade and Cross-National Comparison }\end{array}$ & Jiri Vecernik & May 2001 \\
\hline $\begin{array}{l}\text { No. } 372 \text { Economic Reform, Democracy and Growth During Post- } \\
\text { Communist Transition }\end{array}$ & Jan Fidrmuc & Mar. 2001 \\
\hline $\begin{array}{l}\text { No. } 371 \text { Do Multinational Enterprises Substitute Parent Jobs for Foreign } \\
\text { Ones? Evidence from Firm Level Panel Data }\end{array}$ & Jozef Konings and Alan Murphye & Apr. 2001 \\
\hline $\begin{array}{l}\text { No. } 370 \text { From Needs to the Market: Changing Inequality of Household } \\
\text { Income in the Czech Transition }\end{array}$ & Jiri Vecernik & Apr. 2001 \\
\hline
\end{tabular}

